\title{
Public R\&D Policies and Private R\&D Investment: A Survey of the Empirical Evidence
}

\author{
Bettina Becker* \\ Aston Business School
}

\begin{abstract}
The importance of R\&D investment in explaining economic growth is well documented in the literature. Policies by modern governments increasingly recognise the benefits of supporting R\&D investment. Government funding has however become an increasingly scarce resource in times of financial crisis and economic austerity. Hence it is important that available funds are used and targeted effectively. This paper offers the first systematic review and critical discussion of what the R\&D literature has to say currently about the effectiveness of major public $R \& D$ policies in increasing private $R \& D$ investment. Public policies are considered within three categories, $\mathrm{R} \& \mathrm{D}$ tax credits and direct subsidies, support of the university research system and the formation of high-skilled human capital, and support of formal R\&D cooperations across a variety of institutions. Crucially, the large body of more recent literature observes a shift away from the earlier findings that public subsidies often crowd-out private R\&D to finding that subsidies typically stimulate private R\&D. Tax credits are also much more unanimously than previously found to have positive effects. University research, high-skilled human capital, and $R \& D$ cooperation also typically increase private R\&D. Recent work indicates that accounting for non-linearities is one area of research that may refine existing results.
\end{abstract}

Keywords: Research and Development; Research and Development Policy; Innovation Policy; Public Funding.

\footnotetext{
* Economics and Strategy Group, Aston Business School, Aston University, Aston Triangle, Birmingham B4 7ET, UK. Tel.: +44 (0)121 204 3339. E-mail: b.becker@aston.ac.uk.
} 


\section{INTRODUCTION}

In the light of the importance of $\mathrm{R} \& \mathrm{D}$ investment in explaining economic growth, it comes as no surprise that analysis of the driving factors of $R \& D$ remains a subject of key methodological and empirical concern to economic researchers. The positive impact of R\&D on growth and productivity has been predicted by a considerable number of theoretical contributions, and a broad corpus of empirical work has supported this result at the firm, industry and country level (see, inter alia, Arrow, 1962a; Romer, 1986, 1990; Grossman and Helpman, 1991; Aghion and Howitt, 1998; Proudman and Redding, 1998; for the theory and, inter alia, Cameron, Proudman and Redding, 2005; Kafouros, 2005; Coe, Helpman and Hoffmaister, 2009; O'Mahony and Vecchi, 2009; Bravo-Ortega and Marin, 2011; for recent empirical evidence).

Policies by modern governments increasingly recognise the benefits of supporting R\&D investment. In part this is testimony to the importance of Nelson's (1959) and Arrow's (1962b) early insights into the motives underlying R\&D investments. In essence, the argument proceeds from the observation that industrial R\&D exhibits a classic public goods problem in that it is both non-rivalrous and not (completely) excludable. If the private rate of return thus is below the social rate of return, as firms are unable to fully appropriate the returns from their $\mathrm{R} \& \mathrm{D}$, private $\mathrm{R} \& \mathrm{D}$ investment has positive externalities and could be lower than socially optimal. The empirical evidence provided in Griliches $(1979,1998)$ confirms that the private rate of return to industry $R \& D$ typically is below the social rate of return. This mismatch of returns provides economic justification for government support of private R\&D.

Government funding has however become an increasingly scarce resource in times of financial crisis and economic austerity. Hence it is important that available funds are used and targeted effectively. The objective of this paper therefore is to offer the first systematic review and critical discussion of what the $R \& D$ literature has to say currently about the effectiveness of major public $R \& D$ policies in increasing private $R \& D$ investment. This review considers direct and indirect effects of policies, different channels through which policies take effect, and types of firms or industries that stand to benefit most from different policies. Based on the review, remaining challenges for future research are identified. 
Public policies are considered within three categories, $R \& D$ tax credits and direct subsidies, support of the university research system and the formation of high-skilled human capital, and support of formal R\&D cooperations across a variety of institutions. There is to date no survey that draws together the existing evidence on the effects of these major types of direct and indirect government support of private R\&D. Moreover there are no individual surveys of the fast growing empirical literatures on the second and third R\&D policy categories. Surveys of the likewise rapidly advancing literature on the first category, $R \& D$ tax credits (Hall and Van Reenen, 2000) and direct subsidies (David, Hall and Toole, 2000; García-Quevedo, 2004), exist essentially only for the early, mainly pre-2000 work. Crucially, the large body of more recent literature observes a shift away from the earlier findings that public subsidies often crowd-out private $R \& D$ to finding that subsidies typically stimulate private $R \& D$. The recent evidence on the effectiveness of tax credits also importantly suggests much more unanimously than concluded in the earlier work that there are positive R\&D effects. This review focuses on the recent empirical evidence. ${ }^{1}$

With regard to university research, specific and general measures of high-skilled human capital, and $R \& D$ cooperation, the more recent empirical evidence also finds a number of positive effects on private $R \& D$ investment.

The paper is structured as follows. As the focus is on the empirical literature, section 2 provides a brief overview of the methodological issues involved in estimating models of R\&D investment. Section 3 first presents the key predictions from theory regarding the R\&D effect of each type of public policy. It then reviews the existing empirical literature and links the results to the theory. Section 4 discusses some remaining questions and challenges for future research. In concluding, section 5 reviews the main results.

\footnotetext{
${ }^{1}$ As the focus is on the empirical literature, the paper concentrates on the seminal thus typically early contributions regarding the theoretical literature.
} 


\section{Methodological ISSUES}

\subsection{Data and measurement of $R \& D$}

The first issue is how to measure and compare R\&D across firms, industries and countries. Input measures, such as R\&D expenditure or R\&D intensity, as well as output measures, such as patents or innovation counts, have been used. One advantage of input measures is that their economic (monetary) value may be taken as homogenous, while the economic value of output measures such as patent counts is heterogeneous. Furthermore, the propensity to patent varies considerably across industries and countries, and even a high patent count need not imply a high level of innovation as some patents may never be implemented. However, because of its input character, higher R\&D spending need not necessarily imply higher innovative output either. In practice, input and output measures appear to be correlated (e.g. Acs and Audretsch, 1988; Bound, Cummins, Griliches, Hall and Jaffe, 1984).

Most of the empirical work on the determinants of $R \& D$ focuses on $R \& D$ expenditures or R\&D intensity. The comparability of the results from studies using different datasets may nonetheless be impeded by the difficulty in measuring the level of $R \& D$ expenditure accurately. Firms are given considerable latitude in what they choose to classify as R\&D, and the definitions used may differ between datasets. Cohen and Mowery (1984), for instance, find that for the same US firms and years, Standard and Poor's Compustat data reported an average of $12 \%$ more R\&D than the Federal Trade Commission's Line of Business Program data, with the difference resulting from the definitions used. The Frascati Manual publishes internationally agreed standards defined by the OECD (OECD, 2002). However, it is not always obvious from the literature whether the data definitions used follow the Frascati Manual. Hall (2006) provides a concise overview of the meaning of the term 'R\&D', its economic analysis and its attribute as an investment.

\subsection{The $R \& D$ equation}

Most studies use as a starting point a simple panel data model of R\&D investment of the form

$r_{i t}=a+\beta^{\prime} X_{i t}+\varepsilon_{i t}$ 
where $i$ indexes the cross-section units, usually firms, industries or countries, $t$ indexes the units of time, usually years, $r$ denotes $R \& D$ expenditure, $X$ denotes the vector of explanatory variables, $\alpha$ is a constant, and $\varepsilon_{i t}$ is the error term. Other than as a convenient empirical starting point for an analysis of the determinants of $R \& D$, (1) may be considered to be the stochastic form of the demand equation for R\&D capital as derived from a CES production function where $R \& D$ and the flow of $R \& D$ investment are proportional to each other in steady state.

Unobserved heterogeneity between the cross-section units, as long as this is broadly stable over time and additive, can be controlled for by including fixed effects in the regression. Examples of these effects are managerial ability, language or culture. Model (1) can thus be re-written as the conventional within-groups or least-squares dummy variables estimator:

$r_{i t}=\gamma^{\prime} X_{i t}+f_{i t}+\varepsilon_{i t}$

where $f$ denotes the fixed effects. Some studies capture common technology shocks and other time-variant common effects by including time dummies in (2).

There are in principle two ways to measure the impact of an $R \& D$ tax credit in an $R \& D$ equation such as (2). The first is a dummy variable equal to one if a credit is available and zero otherwise. While this is simple to use, disadvantages include its relative imprecision, as different firms may face different credit levels, and, if it varies over time, that it is not separately identifiable from time dummies. The second measure, much used in recent studies, is a price variable such as the user cost of $R \& D$, that captures the marginal cost of $R \& D$, whereby the estimated $R \& D$ response is converted to a price elasticity. This measure is somewhat more accurate as it estimates the response directly. ${ }^{2} \mathrm{R} \& \mathrm{D}$ subsidies are similarly measured as a dummy variable or by their financial amount. More recently, subsidy effects have increasingly been inferred from treatment effects analyses comparing 'treated', i.e. subsidy-receiving, and 'untreated' firms. One advantage of such a non-parametric methodology is the availability of a counterfactual.

Measures of geographically localised spillovers from university research to private $R \& D$ include research spending by department and the number of science-specific departments of different quality within a given region and industry. Measures of specific or general high-

\footnotetext{
${ }^{2}$ For a detailed assessment, see Hall and Van Reenen (2000).
} 
skilled human capital include the number of scientists and engineers in a firm, the share of the total number of workers with higher or tertiary education, and years of formal schooling. Dummy variables are typically used to measure whether or not a firm is a member of a joint venture or a formal $R \& D$ cooperative agreement.

There are a number of characteristics of $R \& D$ that suggest this type of investment should not be analysed in a static framework as in (2) but in a dynamic framework. One such characteristic is that $R \& D$ typically behaves as though it has high adjustment costs. Theory suggests these are important because of the high cost of temporary hiring and firing of highly skilled employees with firm-specific knowledge. Firms therefore tend to smooth their R\&D investment over time (Hall, Griliches and Hausman, 1986; Lach and Schankerman, 1988). Hall (1993) reports that at least $50 \%$ of R\&D budgets typically consist of the wages and salaries of highly qualified scientists and engineers, and the more recent figure of $60 \%$ reported in Bond, Harhoff and Van Reenen (2005) suggests that this share has risen somewhat over time.

Another characteristic of $R \& D$ that calls for a dynamic approach is that there is typically a high degree of uncertainty associated with the output of R\&D investment, and sustained commitment to $R \& D$ is often required for projects to be successful. The role of uncertainty is implicit in the early adjustment costs literature in the context of capital investment (Eisner and Strotz, 1963; Lucas, 1967), which captures the role of backward-looking expectations formation through lagged variables. More recently, part of the growing literature on irreversible investment has criticised this essentially ad-hoc approach to the specification of adjustment cost functions. Tobin (1969) made explicit the role of future expectations in qmodels of investment.

Most R\&D studies use standard investment equation methodology to incorporate adjustment cost dynamics into the static R\&D model (2), where the two main approaches are a neoclassical accelerator model with ad-hoc dynamics and an Euler equation as derived from forward-looking dynamic profit maximisation by firms. ${ }^{3}$ As Euler equation respresentations of R\&D investment tend to be little robust or informative (e.g., Hall, 1991; Bond, Harhoff and Van Reenen, 2005), most studies use the former approach to model dynamics by introducing a lagged dependent variable into (2):

\footnotetext{
${ }^{3}$ Hall (1991) and Mairesse, Hall and Mulkay (1999) provide details on the econometric estimation of these models.
} 


\subsection{Endogeneity}

Inclusion of lagged $R \& D$ in (3) requires an instrumental variables estimator in order to avoid the downward bias that can result when using a fixed effects estimator in panels where the number of time periods is small (Nickell, 1981). If the firm or industry responds to expectations of future technological shocks, this may also result in endogeneity bias. In general, strict exogeneity would imply that shocks to current $\mathrm{R} \& \mathrm{D}, \varepsilon_{i}$, do not affect the future values of the explanatory variables, and this assumption clearly does not hold for a dynamic model that includes a lagged dependent variable.

Instrumental variables can further control for endogeneity or simultaneity bias that may plausibly arise from most types of R\&D policy measures in X: Government subsidies provided to the private sector may be endogenous, as the success of an application for funding depends on the characteristics of the firm and the application. Tax competition also implies that government policy and R\&D tax credits may be endogenous. The user cost of $\mathrm{R} \& \mathrm{D}$, for example, is a function of both the tax system and a range of other economic variables, such as the economy's real interest rate. When using a measure of highly qualified human capital as an explanatory variable in an $R \& D$ equation, estimations also need to take account of potential double counting. Indeed, $R \& D$ personnel and $R \& D$ spending have sometimes been used as alternative dependent variables of $R \& D$ regressions.

One instrumental variables technique that has been applied relatively widely in the R\&D panel data literature is the first-differences generalised methods of moments (GMM) estimator (Anderson and Hsiao, 1982; Arellano and Bond, 1991). The first-differencing transformation eliminates the individual fixed effects from the model and in contrast to the fixed effects estimator does not rely on asymptotic consistency in the time dimension. However, this estimator may be subject to large finite sample bias in cases where the instruments available have weak predictive power. This applies in particular when a times series is highly persistent, as is $\mathrm{R} \& \mathrm{D}$, because lags will be poor predictors of future 
outcomes. ${ }^{4}$ Bloom, Griffith and Van Reenen (2002) experiment with both techniques and find that the point estimates are similar, but that the GMM estimates are much more imprecise. Blundell and Bond (1998) show that efficient GMM estimation in the case of very persistent series may be achieved by using the systems approach developed by the authors. This approach is increasingly used in the more recent literature.

\subsection{Parameter heterogeneity}

Although estimations of $R \& D$ equations have been conducted at different levels of aggregation, the majority of the existing work uses firm level (panel) datasets. The models typically assume, and constrain, the R\&D effects of the factors under consideration to be homogeneous across the cross-section dimension of firms, industries or countries. Under this assumption, the estimated coefficients reflect average effects within the sample. While average effects reveal important information, they do not provide any information about potential cross-sectional differences of the R\&D effects. Set against this possible lack of information is the disadvantage of a smaller sample size when estimating sub-samples of firms or industries. Sub-sample estimates may thus be less precise, and interpretation may need to be more cautious. However, relatively low degrees of freedom need not necessarily imply a lack of precision, and authors who have split their samples into such sub-samples have found important differences in the R\&D effects of government policy. Lach (2002), for instance, finds that the effect of subsidies differs between small and large firms. González and Pazó (2008) and Hall, Lotti and Mairesse (2009) report different R\&D effects for hightech versus low-tech firms, and Becker and Hall (2013) confirm the existence of such differences at the industry level. Considering full-sample as well as sub-sample estimates may thus bear useful conclusions for R\&D policies.

\subsection{Model uncertainty}

Differences between studies may also result from the set of control variables included in the regressions. For instance, the precise estimated long-run elasticity of $R \& D$ with respect to

\footnotetext{
${ }^{4}$ See, e.g., Hall, Griliches and Pakes (1986); Lach and Schankerman (1989); Bound, Jaeger and Baker (1995); Blundell and Bond (1998); Blundell, Bond and Windmeijer (2000).
} 
its user cost, while being broadly around -1.0, varies depending on the model specification. Many alternative empirical equations have equal theoretical status, however, so that differences in results from models with different control variables need to be interpreted with care.

\subsection{Non-linearities}

Little attention has so far been paid to potential non-linearities in the relationship between private $\mathrm{R} \& \mathrm{D}$ investment and policy measures. If non-linearities are present, then traditional linear models may be misspecified. Guellec and Van Pottelsberghe de la Potterie (2003) find that the elasticity of private $R \& D$ with respect to a government subsidy has an inverted Ushape for a multi-country OECD sample, which enables them to identify threshold levels of subsidies at which the effect of the subsidy on private R\&D changes sign. Görg and Strobl (2007) provide similar evidenempirical evidence is provided in Woodward, Figueiredo and Guiamares (2006).

\section{PubliC POLICIES In SUPPORT OF PRIVATE R\&D INVESTMENT}

\subsection{R\&D tax credits and direct subsidies}

The classical public finance solution to the problem that private $R \& D$ expenditure has positive externalities and may therefore be lower than socially optimal would be to subsidise the economic activity which creates the positive externality, i.e. private $R \& D$ investment. Two policy tools available to governments are $R \& D$ tax credits and direct subsidies of private $\mathrm{R} \& \mathrm{D}$ projects. The former is a more market-oriented approach, leaving decisions on the level and timing of the investment to the private sector. ${ }^{5}$

\footnotetext{
${ }^{5}$ Of course, even when effective, any judgement as to the desirability of a tax credit would need to be based on a cost-benefit analysis that included deadweight costs and the relabelling of activities as R\&D within corporate accounts (Hall and Van Reenen, 2000). For a detailed microeconomic evaluation of the effects of a tax credit, see Klette, Møen and Griliches (2000). See also Jaffe (2002). For an assessment of the efficiency of public R\&D support at the macroeconomic level, see Cincera, Czarnitzki and Thorwarth (2011).
} 
Generally, when assessing the response of private $R \& D$ spending to a change in its price, it is important to bear in mind the implications of what is known as the 'relabelling' problem (Hall and Van Reenen, 2000): The true impact of a change in the tax credit on companies' $R \& D$ expenditure may be overestimated when using reported $R \& D$ data, as in response to an introduction of or an increase in the tax credit, firms have an incentive to maximise the share of R\&D qualifying for the credit. They may thus move expenses within their accounts so as to ensure correct classification, whereas before the preferential tax treatment indifference with respect to the labelling of $R \& D$ expenses may have led to incorrect classification of at least part of the R\&D spending. Hall and Van Reenen (2000) review some evidence in favour of this hypothesis.

Overall Hall and Van Reenen (2000) conclude in their survey of the pre-2000 literature that tax credits have a significant positive effect on $R \& D$ expenditure, although there is considerable variation in the findings of different studies. The more recent literature more unanimously finds a positive effect, whereby the precise estimated elasticities vary depending on the data, estimation method and model specification.

In a panel data study on the manufacturing sector of nine OECD countries for 1979-1997, Bloom, Griffith and Van Reenen (2002), for instance, estimate a long-run elasticity of R\&D with respect to its user cost of around -1.0. Applying a similar estimation approach, Li and Trainor (2009) obtain a long-run elasticity of around -1.4 for a panel of manufacturing plants in Northern Ireland for 1998-2003, and an elasticity of between -1.5 and -1.8 is reported in Parisi and Sembenelli (2003) for a panel of Italian firms for 1992-1997. Lokshin and Mohnen (2012) and Koga (2003), respectively, find somewhat lower elasticities of - 0.8 for firms in the Netherlands during 1996-2004, and -0.7 for firms in Japan during 1989-1998. Mulkay and Mairesse (2013) report a long-run user cost elasticity of -0.4 for a recent 2000-2007 sample of French firms. For the US and the Canadian manufacturing sectors, respectively, Bernstein and Mamuneas (2005) estimate R\&D own price elasticities of -0.8 and -0.14 . The authors suggest that one reason why the latter elasticity is so low is that much of Canadian R\&D is performed by foreign firms which are not as susceptible to changes in Canadian economic conditions as are domestic firms. Baghana and Mohnen (2009) confirm the long-run elasticity of -0.14 for firms in the Canadian province Québec. Using a non-parametric matching approach, Czarnitzki, Hanel and Rosa (2011) conclude that R\&D tax credits also have a positive impact on Canadian firms' decision whether to conduct any $\mathrm{R} \& \mathrm{D}$ at all. In a rare 
study on a newly industrialised economy, Yang, Huang and Hou (2012) confirm the evidence of a positive R\&D effect of tax credits for Taiwan. One policy conclusion that can be drawn from all of these studies is that fiscal policy measures that reduce the user cost may be expected to increase private $\mathrm{R} \& \mathrm{D}$ expenditure. Overall, the average negative elasticity across the various studies appears to be around unity.

Regarding the effect of direct R\&D subsidies, the surveys of earlier studies conclude that the econometric evidence is ambivalent and that there are additionality effects of public $R \& D$ on private R\&D as well as crowding-out effects (David, Hall and Toole, 2000; GarcíaQuevedo, 2004). David, Hall and Toole (2000), for example, find that a third of the 33 studies under review report substitution effects. However, the more recent research much more unanimously rejects crowding-out and tends to find additionality effects. One criticism of much of the earlier work has been that it neglects the problem of sample selection bias, in that R\&D intensive firms may be more likely to apply for a subsidy (David, Hall and Toole, 2000). Since it is likely that these firms would have undertaken at least part of the R\&D even in the absence of the subsidy, the results may have been biased towards finding crowding-out effects. The availability of new econometric techniques that control for the selection bias is thus likely one reason for the shift away from finding crowding-out effects.

In this vein, applying a matching framework to samples of French and Italian firms, respectively, Duguet (2004) and Carboni (2011) reject crowding-out and find that public subsidies on average increase private R\&D. Czarnitzki and Hussinger (2004) confirm these results for the German business sector. Aerts and Schmidt (2008) provide similar results for firms in Flanders and in Germany, using a conditional difference-in-differences estimator with repeated cross-sections. Employing parametric and semiparametric two-step selection models, Hussinger (2008) further finds evidence of additionality effects of publicly funded $R \& D$ on private $R \& D$ investment per employee in German manufacturing. Comparing the results of seven matching methods, a selection model and a difference-in-differences estimator for a dataset of Italian firms, Cerulli and Potì (2012) also reject full crowding-out of private $\mathrm{R} \& \mathrm{D}$ on average. Conducting a treatment effects analysis for manufacturing firms in Turkey as a developing country, Özçelik and Taymaz (2008) further corroborate the evidence of additionality effects.

Regarding recent panel data regression analyses, the result of additionality effects from the treatment effects analysis in Özçelik and Taymaz (2008) holds also for the various regression 
analyses conducted in the study. Klette and Møen (2012) compare the results of two panel fixed effects studies on similar Norwegian firm data for the pre-2000 and post-2000 time periods 1982-1995 and 2001-2007. The authors conclude that the fact that their study on the earlier period does not find any significant degree of additionality, while the study by Henningsen, Haegeland and Møen (2012) on the later period does find additionality, suggests that the effectiveness of this policy tool has improved over time. Using a dynamic panel fixed effects instrumental variables estimator in an analysis of UK manufacturing industries for 1993-2000, Becker and Pain (2008) find a positive effect of the share of business R\&D funded by the government on the level of R\&D. The study thus indicates that the decline in the share of manufacturing R\&D financed by the government between 1992 and 1997 plays an important role in the explanation of the comparatively poor R\&D performance of the UK seen over the 1990s. In a further dynamic panel data regression analysis, Bloch and Graversen (2012) obtain additionality effects of public R\&D funding for a sample of Danish firms. For the business enterprise sector of 21 OECD countries, Falk (2006) does not find a significant effect in dynamic panel data models. Nonetheless, the general conclusion from the post-2000 empirical evidence must be that public R\&D subsidies succeed in significantly stimulating private $R \& D$ investment.

There is growing evidence that public subsidies are particularly effective in increasing R\&D of small firms, which are likely to be more financially constrained. Small firms have, for instance, less collateral in terms of existing assets to be used for obtaining loans, and as a group they are likely to include more young firms. ${ }^{6}$ Related to this, large firms' greater ability to secure funding for risky projects given capital market imperfections is one of the arguments put forward in support of the hypothesis that R\&D increases more than proportionately with firm size, following Schumpeter $(1939,1942)$. One relevant study is Lach (2002) which uses a difference-in-difference estimator and finds for a sample of firms in Israel that subsidies for the small firms temporarily crowd out these firms' R\&D, but have a strong stimulative effect after the first year of the subsidy. The author argues that this may reflect the fact that firms which receive the subsidy are committed to implement the subsidised project, but that this commitment may have led firms to temporarily scale down non-subsidised projects due to the serious skilled labour shortage that characterised the economic environment in Israel over the sample period 1990-1995. Subsidies for the large

\footnotetext{
${ }^{6}$ For a survey of the empirical evidence on financial constraints for R\&D by small versus large and young versus mature firms, see Hall (2002) and Hall and Lerner (2010).
} 
firms in the sample are statistically insignificant. Most subsidies are granted to the large firms, however, which may explain the result that the average effect for the pooled sample, while positive, also is insignificant. These findings are interpreted as indicating that large firms get subsidies for projects that would also have been undertaken in the absence of the subsidy, whereas small firms use the subsidy to finance additional projects. From a policy point of view, the subsidy funds should therefore be redirected to the smaller firms. Using Finnish data, Hyytinen and Toivanen (2005) further show that when there are economically significant capital market imperfections, small and medium-size firms in industries that are more dependent on external finance invest relatively more in $R \& D$ when more public funding is (potentially) available. Overall these results suggest that, on the one hand, subsidies targeted at financially constrained firms may raise overall private $R \& D$ spending, and that, on the other hand, policies designed to improve these firms' access to external finance might reduce the need for $\mathrm{R} \& \mathrm{D}$ subsidies. ${ }^{7}$

These conclusions are also compatible with evidence found by Almus and Czarnitzki (2003) for a transition economy, for which capital market imperfections may a priori also be expected to be relatively more pronounced. Applying a non-parametric matching approach to post-reunification cross-sections from the 1990s for East Germany, the study finds additionality effects of all public R\&D subsidies on average. Czarnitzki and Licht (2006) moreover find that the additionality effect on firms' $R \& D$ and innovation input was more pronounced in Eastern Germany during the transition period than in Western Germany. One conclusion drawn by Czarnitzki (2006), however, is that while the subsidies were initially intended to accelerate the transformation process of East Germany from a planned to a market economy, the continuing high level of subsidisation may imply inefficiencies as market forces are weakened. ${ }^{8}$

González, Jaumandreu and Pazó (2005) model firms' decisions about performing R\&D when some government support can be expected. Applying a semistructural framework to

\footnotetext{
${ }^{7}$ There is some first evidence that award of a government subsidy may provide a positive signal about firm quality and thus help a firm attract additional private funding, hence easing the adverse effect of capital market imperfections. Meuleman and De Maeseneire (2012) provide compelling evidence that obtaining an R\&D grant results in better access to long-term debt and to a lesser extent short-term debt for small and medium-size firms in Belgium. Feldman and Kelley (2006) find that R\&D grants facilitate attracting venture capital for US firms that participate in the Advanced Technology Program.

${ }^{8}$ One novelty of this study is that it takes into account non-R\&D performing firms and the endogeneity of their decision as to whether or not to invest in R\&D. The study thereby explicitly considers the fact that a large share of small firms do not invest in R\&D due to a lack of financial resources.
} 
Spanish firm data, the authors find that public subsidies stimulate private R\&D spending. However, there is only a very slight increase for those firms that would perform R\&D anyway, whereas some small firms would not perform any R\&D in the absence of (expected) public funding. Similarly to Lach (2002) the authors point out that subsidies are mainly awarded to firms that would have performed the R\&D anyway, and that this suggests that public policy tends to neglect the inducing dimension of public funding. The importance of this dimension is also underlined by the results in Hall, Lotti and Mairesse (2009) who find for small and medium-size Italian firms that non-R\&D performing firms are more likely to start investing in $R \& D$ if they receive a subsidy. In a cross-country analysis, Czarnitzki and Lopes Bento (2012) conclude that private R\&D in Belgium, Germany, Luxembourg and Spain would benefit from an extension of public R\&D subsidies to currently non-subsidised firms. Applying a matching approach to the same dataset as González, Jaumandreu and Pazó (2005), González and Pazó (2008) moreover find that, similarly as for small firms, R\&D subsidies are more effective for firms operating in low-tech sectors, which the authors argue is probably also due to the inducement effect. In a study of UK manufacturing industries, Becker and Hall (2013) find that a higher share of government-funded R\&D has a positive effect only for the low-tech industry group while being insignificant for the high-tech industry group. These results also suggest that high-tech firms substitute incremental public funding for internal funding.

Comparing the private $R \& D$ effects of EU versus national grants, using a sample of German firms, Czarnitzki and Lopes Bento (2011) conclude that the former yield higher effects than the latter, if funding is received from only one of the two sources. Two reasons are suggested: First, EU grants may on average distribute larger subsidies, or, second, their requirements might be such that only those firms that are most likely to top up the grant with private funding more substantially comply. The largest R\&D effects are obtained through simultaneous funding from both sources, and Czarnitzki and Lopes Bento (2013) confirm that simultaneous receipt of multiple grants does not cause crowding-out.

There is both early and recent evidence of a different time pattern of the effects of tax credits and direct subsidies. Tax credits have a significant effect on R\&D expenditure mainly in the short run, but only little in the long run, whereas subsidies have a positive effect in the medium to long run, but less so in the short run. Hence the effect of tax credits is quicker than that of direct subsidies (David, Hall and Toole, 2000; Guellec and Van Pottelsberghe de la 
Potterie, 2003). The earlier study suggests that this time pattern at least in part likely reflects the fact that the tax offsets against earnings occur for $R \& D$ projects chosen by firms themselves, the incentives of which probably favour projects that will generate greater private profits in the short run. By contrast, subsidies apply to projects selected by the government, which may be of a long-term nature and create new opportunities that may induce firms to start further projects with internal funding at a later stage, as pointed out in the more recent study. The study further suggests that tax credits and direct subsidies are substitutes in that an increase in one dampens the effect of the other on business $R \& D$. These results indicate that the design and implementation of the two policy tools may be more effective if performed in a coordinated way.

There is some first evidence that the effect of a public subsidy on private R\&D may have an inverted U-shape. Guellec and Van Pottelsberghe de la Potterie (2003) obtain the strongest private $R \& D$ effects for medium average subsidisation rates of $4-11 \%$, while rates above $20 \%$ are found to be associated with the substitution of government funds for private funds. Görg and Strobl (2007) similarly find an inverted U-curve effect for indigenous Irish manufacturing firms. These studies thus indicate that large grants may more likely act to finance private R\&D activity that would have been undertaken anyway. From a policy point of view, the non-linear effect suggests that for any given public R\&D budget, it may be more effective to grant some intermediate level of support to a larger number of firms than to provide a large amount of support to fewer firms.

With respect to the potential importance of international tax differences, Bloom and Griffith (2001) conclude in a cross-country analysis of eight OECD countries that R\&D in one country responds to a change in the $R \& D$ tax credit in another country. This result suggests that at least part of the reason for the international mobility of R\&D may be related to the increasing tax subsidies to $R \& D$ offered in many countries. One implication for $R \& D$ tax policy then is that the positive $R \& D$ effect of tax credits may be higher than previously estimated and increasing over time. Foreign tax competition may moreover become increasingly important as impediments to capital mobility come down.

Concluding, economists have generally been sceptical regarding the efficacy of tax credits, one reason being the view that $R \& D$ was not very sensitive to changes in its price. The recent evidence suggests much more unanimously than concluded in surveys of the earlier work that $R \& D$ tax credits have a positive effect on private $R \& D$ investment. Generally, the negative 
demand elasticity of $R \& D$ with respect to its own tax price is estimated to be broadly around unity, at least in countries with a tax credit. The recent evidence predominantly also suggests that public $R \& D$ subsidies succeed in stimulating private $R \& D$. The additionality effect has been shown to be particularly prevalent for small firms, which are more likely to experience external financial constraints. Moreover, these firms are more likely to start investing in R\&D if they receive a subsidy. On the one hand, these results provide strong support of such government funding schemes. On the other hand, a number of studies report that most of the funding is awarded to larger firms that would have performed the R\&D even in the absence of the public subsidy, which suggests that in these cases subsidies could be targeted more effectively. Indeed, Czarnitzki and Ebersberger (2010) report that governments in general prefer to grant $R \& D$ subsidies to larger firms and that this is a common general criticism of the distribution of subsidies: This kind of distribution may contribute to a higher concentration of $R \& D$, the persistence of leadership in markets and higher barriers to entry, and thus eventually reduce competition. It may also be the case that a tax credit rather than a subsidy could be the more effective policy instrument for firms that are likely to simply substitute incremental public funding for internal funding, as the tax credit supports the private $R \& D$ that is actually expended by the firms. There is some evidence that both policy tools may be more effective if performed in a coordinated way and that tax credits are the more effective short-run policy option, while direct subsidies are the more effective medium to long-run policy. There is also some indication that the effect of a subsidy may have an inverted U-shape, so that subsidy levels that are too high crowd out private R\&D, while intermediate levels stimulate private $R \& D$. This could imply that it may be more effective to grant some intermediate level of support to a larger number of firms than to provide a larger amount of support to fewer firms. To date there are, however, only very few studies that investigate the relative effect of both tools or allow for a potential non-linear effect. Table 1 summarises the key features of studies that represent the main results from the literature.

<Table 1 about here> 


\subsection{Support of the university research system and the formation of high-skilled human capital}

A growing body of evidence indicates that private $R \& D$ benefits from geographically localised knowledge spillovers from university research and from the availability of highskilled human capital resources. The notion that knowledge spillovers be localised goes back at least to Marshall's (1920) concept of the external economies. He illustrates this with the example of industry localisation and identifies three reasons for localisation, which can also be found in most of the more recent literature on regional economics and economic geography: A pooled market for workers with industry-specific skills, support of the production of non-tradable specialised inputs, and informational spillovers between firms that give clustered firms a better production function than isolated firms. The theoretical foundation of the geography of innovation is provided in Krugman (1991a, b) who shows how a country can endogenously develop into an industrialised 'core' region and an agricultural 'periphery' region.

An early case study which indicates that knowledge spillovers from university research may be a driving factor of firms' choice of location was provided by Dorfman (1983). Her results indicate that high-technology firms sought to locate close to universities, pointing to the importance of the MIT for the development of Boston's 'high technology' Route 128 and of Stanford University for the location of 'Silicon Valley'. Related to this, Nelson (1986) argues in the first formal indication of localised knowledge spillovers from universities to firms, that university research rarely in itself generates new technology, it rather enhances technological opportunities and the productivity of private R\&D. In accordance with this, the much-cited study by Jaffe (1989) provides evidence of a large significant positive effect of university research on industry R\&D spending within US states and concludes that a state that improves its university research system will increase local innovation by attracting industrial R\&D. In support of Dorfman's (1983) early results, Woodward, Figueiredo and Guimaraes (2006) more recently find for the US that R\&D expenditures at universities positively affect the location decision of new high-tech plants in a county. This positive effect 
extends up to a maximum distance of approximately 145 miles between the university and the new plant. $^{9}$

More recently there has been a growing number of studies using data for countries other than the US. Applying a modified version of Jaffe's (1989) R\&D model to French data, Autant-Bernard (2001), for instance, finds positive externalities from public research to private $R \& D$ expenditures, and that these externalities are strongest within the same geographical area. Karlsson and Andersson (2009) provide evidence that industrial R\&D in Sweden tends to increase in locations that offer high accessibility to university R\&D. Abramovsky, Harrison and Simpson (2007) examine the relationship between the co-location of the average number of private sector $R \& D$ firms and university research departments in 111 postcode areas in the UK. The authors match data for R\&D labs in six product groups with data from the Research Assessment Exercise on the quality of university research. The strongest evidence for co-location is found for pharmaceutical business R\&D and the most highly ranked chemistry university departments. Overall the results raise the possibility that private sector R\&D may benefit from proximity to both, frontier basic university research and also more applied university research. The authors note that while the latter may be considered as low-quality research in terms of the Research Assessment Exercise and consequent university funding allocations, it may be relevant in some areas of technology transfer and in attracting foreign-owned R\&D. In a related analysis, Abramovsky and Simpson (2011) confirm that pharmaceutical firms locate their R\&D facilities close to frontier chemistry university departments. In addition, the results for the chemicals and vehicles industries potentially indicate the presence of knowledge flows between $R \& D$ activity and production activity. Conditional on location, the evidence for these latter two industries is again consistent with geographic proximity facilitating knowledge flows from universities. Rosa and Mohnen (2008) measure knowledge transfers from universities to firms by the amount of R\&D payments made by firms to universities. The authors' empirical results for Canadian data corroborate the mounting evidence that a decrease in distance increases spillovers.

The existing literature on the US and a variety of other countries hence predominantly concludes that private $R \& D$ benefits from geographically localised knowledge spillovers

\footnotetext{
${ }^{9}$ After controlling for other determinants of high-tech start-ups, university R\&D is found to have only a small marginal effect on county location probabilities. This result might at least in part be due to the high-technology boom of the 1990s sample period, which exhibited its own specific start-up dynamics.
} 
from university research. This has important implications for regional economic and development policies, and for the evaluation and funding of university research. One role this literature ascribes to regional $R \& D$ policy is to facilitate and support the formation of regional clusters of university and private $\mathrm{R} \& \mathrm{D}$ activity in order to exploit agglomeration economies. Supporting university research is likely to enhance regional technological opportunities and the productivity of private sector R\&D. Improving the university research system and facilitating spillovers to the private sector has been shown to raise local private R\&D spending. There is moreover some evidence that proximity to university research matters especially in high-tech sectors, which indicates that at least part of the spillovers are sector-specific and not just the diffuse effect of a large research university. Hence it could be effective for government support of university research to target in particular those sectors in which spillovers are found to be largest. The transmission channels of these knowledge spillovers as identified in the literature include direct personal interactions, university spin-off firms, consultancy, and university supply of a pool of highly-trained graduates for employment in industry. ${ }^{10}$

This last channel suggests that $\mathrm{R} \& \mathrm{D}$ conducive government support of the university system extends from the research side to the education side. Consistent with this, there is growing evidence that confirms important positive R\&D effects of high-skilled human capital resources. These include highly qualified scientists and engineers (Adams, Chiang, Starkey, 2001; Adams, Chiang, Jensen, 2003; Becker and Pain, 2008), and more generally the share of the number of workers with higher education in the total number of workers (García and Mohnen, 2010), the share of the population with tertiary education in the total working age population (Wang, 2010) and years of formal schooling (Kanwar and Evenson, 2003). This strand of the literature thus suggests a role for education policies and human capital investment in increasing private $R \& D$. Table 2 summarises the key features of studies that represent the main results from the literature.

<Table 2 about here>

\footnotetext{
${ }^{10}$ Another channel is formal cooperation agreements, which are discussed in section 3.3.
} 


\subsection{Support of formal $R \& D$ cooperation}

There is a growing literature that suggests positive private $R \& D$ effects of $R \& D$ cooperation between a variety of institutions. A firm's membership of a research joint venture has the obvious advantage that it may enable the firm to overcome a cost-of-development barrier that may otherwise prevent $R \& D$ investment, if $R \& D$ requires a minimum threshold investment to be effective at all. Another benefit is the reduction of wasteful duplication of R\&D. These benefits are set against the potential adverse outcome that participants will tend to free-ride on each other's $R \& D$ investments in case of sufficient positive externalities from each firm's R\&D efforts, or curtail competition in other stages of the firms' interaction, as emphasised in the theoretical contribution by Kamien, Mueller and Zang (1992). ${ }^{11}$ Imperfect ability to assimilate the returns from $R \& D$ and innovation increases the incentive to free-ride (Shapiro and Willig, 1990; Kesteloot and Veugelers, 1995). In their pioneering work on cooperative and noncooperative R\&D in duopoly, D'Aspremont and Jacquemin (1988) show that in the presence of large spillovers, $R \& D$ cooperation leads to higher $R \& D$ spending by duopolists compared to the competitive case. A symmetric result is that for small spillovers, $R \& D$ cooperation reduces $R \& D$ spending by the firms. Regarding empirical testing and public policy, these results ascribe a central role to the degree of $R \& D$ externalities in the industry. When attempting to assess the welfare effects of $R \& D$ cooperation, one challenge for research is to take into account the factors that affect the level of spillovers through time. In an extension of the model by D'Aspremont and Jacquemin (1988), Kamien, Mueller and Zang (1992) show that if firms create a research joint venture and also share information in that they cooperate on their $R \& D$ expenditure to maximise combined profits, i.e. they are cartelised in the R\&D stage, consumer plus producer surplus are maximised. Cassiman and Veugelers (2002) point out that little is known today about the complementarities between a firm's own R\&D programmes, cooperative agreements in $R \& D$, and external technology acquisitions, and that a better understanding of these issues may enhance firms' ability to appropriate potential spillovers from $R \& D$ cooperation. $R \& D$ cooperation has played an increasing role in firms' innovative activities (Hagedoorn, 2002). Surveys of the industrial organisation and strategic management literatures on partner motives and outcomes of research joint ventures, or more generally on the theory of $R \& D$ cooperation, are provided by

\footnotetext{
${ }^{11}$ Dixit (1988) provides an analysis within the framework of international competition.
} 
Hagedoorn and Narula (1996), Hagedoorn, Link and Vonortas (2000), Caloghirou, Ioannides and Vonortas (2003) and Sena (2004).

In an empirical analysis, Irwin and Klenow (1996) conclude that among firms who participated in Sematech, a joint R\&D consortium of US semiconductor producers that was formed to develop new technologies for the production of computer chips, there was a drop in the total level of R\&D expenditure. They interpret this as supporting the `sharing' hypothesis, with information flows reducing duplicative $R \& D$, allowing members to spend less on $R \& D$ than before. This is contrasted with the 'commitment' hypothesis of higher joint R\&D expenditure on high-spillover types of R\&D. Adams, Chiang and Jensen (2003) find that cooperation between federal laboratories and firms has a positive impact on private $R \& D$ expenditures and that no other channel of technology transfer from federal laboratories exerts a comparable effect. The authors point out that arrangements that strive to ensure effort by both, firms and federal laboratories, are required for technology transfer to be successful.

A first empirical insight into the potential effect of industry-university cooperative research centres on industry R\&D expenditure is provided by Adams, Chiang and Starkey (2001) for the US. These centres are defined as "...small academic centers to foster technology transfer between universities and firms" (op. cit. p. 73). The results suggest that the development of these centres has fostered knowledge spillovers between universities and member firms. When the authors differentiate between National Science Foundation cooperative research centres and others, the effect is significant only for the former. However, the authors note that the coefficient may be biased upward as the centres are matched to larger and more productive laboratories. Two interpretions given by the authors are, first, that industryuniversity cooperative research centres provide new projects and stimulate industrial research, and, second, that larger laboratories are attracted to them. Hall, Link and Scott (2003) examine the performance of 54 industry-university projects funded by the US Advanced Technology Program which combines public funds with private investments for the creation and application of generic technology needed to commercialise new technology rapidly. The study finds that projects with university involvement are more likely to be in new technological fields where $R \& D$ is closer to science and that, therefore, such projects experience more difficulty and delay, but are more likely not to be aborted prematurely. The authors' interpretation is that universities are contributing to basic research awareness and insight among partners in the funded projects. With respect to geographic proximity, Ponds, 
Van Oort and Frenken (2007), using a sample of science-based industries in the Netherlands, find that proximity matters more when cooperating partners have different institutional backgrounds, such as universities and firms, than for organisations with similar institutional backgrounds. Geographic proximity may thus help overcome institutional differences between cooperators. $^{12}$

Recent research indicates that spillover effects through $R \& D$ cooperation may also be mediated. Using a sample of Belgian manufacturing firms, Cassiman and Veugelers (2002) provide evidence that firms are more likely to cooperate on $R \& D$ if they believe that external information flows, i.e. incoming knowledge spillovers, are probably important. Firms with more effective appropriation of the returns from their $R \& D$, i.e. with lower outgoing spillovers, are also more likely to cooperate on R\&D. However, the study's results suggest differences in the effects of incoming spillovers on the one hand and of appropriability on the other hand on the type of $R \& D$ cooperation sought. Incoming spillovers positively affect the probability that firms will cooperate with research institutes, such as universities and public or private research laboratories. This indicates that those firms which find the publicly available pool of knowledge more important as an input to their innovation process have a higher probability of benefiting from cooperative R\&D agreements with research institutes. Appropriability has no significant impact on this type of cooperation, which is supported by Veugelers and Cassiman (2005) who argue that the more generic and uncertain nature of these R\&D projects involves less intellectual property issues. Related to this, Hall, Link and Scott (2001) note that when research results are uncertain, neither party is able to define meaningful boundaries for any resulting intellectual property issues, and so it is then less likely that appropriability is an insurmountable issue. In contrast, appropriability positively affects the probability of firms' cooperation with customers and suppliers (Cassiman and Veugelers, 2002). The authors argue that this result suggests that only firms which can sufficiently protect their proprietary information are willing to engage in cooperative agreements with downstream and upstream firms, because the outcome of these more applied research projects, that is commercially sensitive information, often leaks out to competitors through common suppliers or customers.

\footnotetext{
${ }^{12}$ This result is consistent with an earlier finding by Adams (2002), who reports for US data that university spillovers to private $R \& D$ are more localised than industrial spillovers to private $R \& D$.
} 
There is a growing number of studies that apply the ideas in Cassiman and Veuglers (2002) to data for other countries. Schmidt (2005), for instance, finds that incoming spillovers and in particular appropriability matter for the decision by German manufacturing firms' to cooperate on R\&D. For a sample of Spanish firms, Lopez (2008) in addition finds that strategic methods to protect the returns from $R \& D$ are particularly important for firms' $R \& D$ cooperation with direct competitor firms. This conclusion is in line with the respective results from the multicountry study for France, Germany, Spain and the UK by Abramovsky, Kremp, Lopez, Schmidt and Simpson (2009). While cooperation among competitor firms is not investigated in Cassiman and Veugelers (2002) due to a lack of data, the result is nonetheless consistent with this study's conclusion of the importance of protection from the leakage of commercially sensitive information to competitors. The findings in Belderbos, Carree, Diederen, Lokshin and Veugelers (2004) for the Netherlands further reflect greater appropriability concerns for cooperation between firms. Overall these studies thus suggest that the free-rider problem may be more serious within direct competitor agreements and hence that there is a role for government policy in providing appropriate intellectual property protection mechanisms.

The latter study moreover shows that firms tend to gravitate to the cooperation type that has the highest value in terms of source-specific incoming knowledge. Spillovers from universities and research institutes have a positive effect on all types of cooperation, i.e. cooperation with direct competitors, customers, suppliers, and research institutions. The authors argue that this result indicates that knowledge from universities and research institutes is more generic in nature and improves the technological opportunities and general effectiveness of a firm's own $R \& D$ and its $R \& D$ cooperation strategies. These observations hence are in accordance with those made by Cassiman and Veugelers (2005) and Hall, Link and Scott (2001) mentioned above, and those that suggest that university research enhances technological opportunities and the productivity of private $R \& D$, as discussed in the previous section.

Consistent with the theoretical argument presented above, most empirical studies that examine the relevance of cost-sharing conclude that this is an important element in a firm's decision to cooperate on R\&D (see e.g. Abramovsky, Kremp, Lopez, Schmidt, Simpson, 
2009, and the references therein). ${ }^{13}$ There is also some evidence that suggests that public subsidies can stimulate R\&D cooperation. ${ }^{14}$ First evidence on the relationship between subsidies for individual firm level research, research cooperation, and subsidies for cooperative research is provided by Czarnitzki, Ebersberger and Fier (2007). Using a sample of West German and Finnish firms, the study shows that firms that either receive individual public subsidies or cooperate on research would increase their R\&D spending if they combined the two. This result supports the notion that public subsidies for R\&D cooperation may be another means of raising private $R \& D$.

Furman, Kyle, Cockburn and Henderson (2006) conclude that if competition between firms has a negative effect on $R \& D$, there may be a trade-off between, on the one hand, a firm's incentive to locate close to for example universities in order to benefit from their locally generated public knowledge, and, on the other hand, the incentive to avoid geographically close competition with rival private firms which may choose the same nearuniversity location. One way around this trade-off may be the formation of cooperative R\&D centres so as to turn competitors into cooperators. This again suggests a potential role for government policy in terms of providing appropriate incentive structures.

Taken together, the results from this strand of the literature suggest that governments may increase private $R \& D$ spending by facilitating and incentivising $R \& D$ cooperation. Policy measures include provision of direct funding for various forms of $R \& D$ cooperation and provision of appropriate intellectual property protection mechanisms. There exists some first evidence that geographic proximity may help to overcome institutional differences between cooperators, which suggests another rationale for facilitating and supporting regional clusters of $R \& D$ activity in order to exploit agglomeration economies. Table 3 summarises the key features of studies that represent the main results from this literature.

<Table 3 about here>

\footnotetext{
13 Similarly to the positive signal of the award of a government subsidy (see footnote 7), recent research suggests that being a partner in horizontal R\&D collaboration may also alleviate liquidity constraints by acting as a positive signal about firm quality and expected success of a project (see Czarnitzki and Hottenrott, 2012, and the references therein).

${ }^{14}$ There are, of course, a number of other determinants of R\&D cooperation, an exploration of which is beyond the scope of this paper. The interested reader is referred to the surveyed studies.
} 


\section{QUESTIONS AND CHALLENGES FOR FUTURE RESEARCH}

The literature on the effects of public $R \& D$ policies on private $R \& D$ investment allows for a number of conclusions to be drawn about what policy measures likely incentivise further private $\mathrm{R} \& \mathrm{D}$. Likewise, there are important issues that remain unresolved, and others that have not been considered in research to date. A few of these issues are discussed in the following.

Government R\&D tax credits usually are assumed to be exogenous, but tax competition implies that they may be endogenous. In this respect, Hall and Van Reenen (2000) point out that understanding the process by which different tax credits are conceived, for instance why and when governments introduce tax breaks, is as important as evaluating their effect. More evidence on the relationship between the effect of a subsidy and the size of the subsidy, through estimating non-linear models, may also usefully inform policy in the light of the scarce evidence on the inverted U-curve effect of subsidies. Furthermore, there has been little research to date on the way that award of direct public R\&D subsidies could be a signal about firm quality that helps a firm attract additional private funding and that hence potentially eases the effect of capital market imperfections. Further utilisation of international panel data seems another promising way forward: Identification of R\&D tax credit or subsidy effects on private $R \& D$ is difficult for studies of single countries, as these policies are correlated with other policies aimed at increasing the appropriability of research benefits to firms that invest in areas of new technological opportunity.

The mounting empirical evidence which suggests that geographic proximity is important for knowledge spillovers from university research to private research says relatively little about the actual mechanisms of this knowledge transfer, albeit some have been identified more generally. It is therefore difficult to suggest specific policy recommendations, as for each transmission mechanism there is varying potential for market failures, as pointed out in Abramovsky, Harrison and Simpson (2007). The mechanisms of knowledge transfer may also differ across industries. Future research to identify the precise mechanisms at work could therefore be highly informative. Moreover, it would be useful to analyse further whether geographic proximity has any impact not just on the quantity but also on the quality of the transferred knowledge (Rosa and Mohnen, 2008). More explicit modelling of the endogeneity 
of the location of research and any impact this may have on research findings would also be useful.

Developing in more detail the importance of distinguishing between incoming and outgoing spillover measures for a firm's R\&D cooperation decisions also ought to be part of the future research agenda, as emphasised in Cassiman and Veugelers (2002). More evidence on the private $R \& D$ effects of public subsidies for different types of $R \& D$ cooperation could also usefully inform policy. Furthermore, the strength of intellectual property protection has been shown to have important effects on R\&D cooperation between otherwise rival firms and between firms and their customers and suppliers, but has also received relatively little attention to date.

Evaluation studies of the effectiveness of existing policy measures also will be an important element of future work, in particular in the light of tight government resources in times of financial crisis and economic austerity.

Concluding, the overriding motivation for future research needs to be the search for appropriate policy design so as to increase private investment in R\&D and generate positive returns for economic growth.

\section{Conclusions}

This paper has surveyed the literature on the effects of major public R\&D policies on private $R \& D$ investment. These policies include $R \& D$ tax credits and subsidies, support of the university research system and the formation of high-skilled human capital, and support of formal R\&D cooperation. The main conclusions from the literature on each of these three broad types of public policies are summarised in the following.

Economists have generally been sceptical regarding the efficacy of tax credits, one reason being the view that $R \& D$ was not very sensitive to changes in its price. The recent evidence suggests much more unanimously than concluded in surveys of the earlier work that R\&D tax credits have a positive effect on private $R \& D$ investment. Generally, the negative demand elasticity of R\&D with respect to its own tax price is estimated to be broadly around unity, at least in countries with a tax credit. The recent evidence predominantly also suggests that 
public $R \& D$ subsidies succeed in stimulating private $R \& D$, while the earlier literature much more often found crowding-out effects. The additionality effect has been shown to be particularly prevalent for small firms, which are more likely to experience external financial constraints. Moreover, these firms are more likely to start investing in R\&D if they receive a subsidy. On the one hand, these results provide strong support of such government funding schemes. On the other hand, most of the funding is often awarded to larger firms that would have performed the $R \& D$ also in the absence of the public subsidy, which suggests that in these cases subsidies could be targeted more effectively. It may also be the case that a tax credit rather than a subsidy could be the more effective public policy instrument for firms that are likely to simply substitute incremental public funding for internal funding, as the tax credit supports the private $R \& D$ that is actually expended by the firms. There is some evidence that both policy tools may be more effective if performed in a coordinated way and that tax credits are the more effective short-run policy option, while direct subsidies are the more effective medium to long-run policy. There is also some indication that the effect of a subsidy may have an inverted U-shape, so that subsidy levels that are too high crowd out private $R \& D$, while intermediate levels stimulate private $R \& D$. This could imply that it may be more effective to grant some intermediate level of support to a larger number of firms than to provide a larger amount of support to fewer firms. To date there are, however, only very few studies that investigate the relative effect of both tools or allow for a potential non-linear effect.

The existing literature examining the effects of geographically localised knowledge spillovers from university research on private $R \& D$ predominantly concludes that these are positive. This has important implications for regional economic and development policies, and for the evaluation and funding of university research. One role this literature ascribes to regional $R \& D$ policy is to facilitate and support the formation of regional clusters of university and private R\&D activity in order to exploit agglomeration economies. Supporting university research is likely to enhance regional technological opportunities and the productivity of private sector R\&D. Improving the university research system and facilitating spillovers to the private sector has been shown to raise local private $R \& D$ spending. There is moreover some evidence that proximity to university research matters especially in high-tech sectors, which indicates that at least part of the spillovers are sector-specific and not just the diffuse effect of a large research university. Hence it could be effective for government support of university research to target particularly those sectors in which spillovers are 
found to be largest. The transmission channels of knowledge spillovers from university research to private research as identified in the literature to date include direct personal interactions, university spin-off firms, consultancy, and university supply of a pool of highlytrained graduates for employment in industry. This last channel suggests that $R \& D$ conducive government support of the university system extends from the research side to the education side. Consistent with this, there is growing evidence that confirms important positive R\&D effects of high-skilled human capital resources. These include highly qualified scientists and engineers and more generally the share of the number of workers with higher education in the total number of workers, the share of the population with tertiary education in the total working age population, and years of formal schooling. This literature thus suggests a role for education policies and human capital investment in increasing private R\&D.

Another channel for knowledge spillovers between research institutes and private research, and between firms, are formal $R \& D$ cooperation agreements. Taken together, the results from this growing literature suggest that governments may increase private $R \& D$ spending by facilitating and incentivising $R \& D$ cooperation. External information flows, i.e. incoming knowledge spillovers, and more effective appropriability of the returns to $R \& D$, i.e. lower outgoing spillovers, have been shown to increase the likelihood of R\&D cooperation in general. In particular, incoming spillovers positively affect the probability that firms will cooperate with research institutes, such as universities and public or private research laboratories. Appropriability is less important for these types of cooperations due to the more generic and uncertain nature of such $\mathrm{R} \& \mathrm{D}$ projects, involving less intellectual property issues. In contrast, appropriability positively affects the probability of firms' cooperation with customers and suppliers and with direct competitors, where potential leakage of commercially sensitive information may prevent cooperation. Policy measures in support of $\mathrm{R} \& \mathrm{D}$ cooperation thus include provision of appropriate intellectual property protection mechanisms and direct cooperation subsidies. There exists some first evidence that geographic proximity may help to overcome institutional differences between cooperators, which suggests another rationale for facilitating and supporting regional clusters of R\&D activity in order to exploit agglomeration economies.

Recent evidence moreover suggests that award of an R\&D subsidy or partnership in horizontal $R \& D$ cooperation may act as positive signals about the quality of a firm and the 
expected success of a project and thus enable a firm to attract additional private funding, hence easing the adverse effect of capital market imperfections.

The advances as well as the gaps in the literature to date point to avenues of research the pursuit of which seems interesting and valuable to better understand the available range of public $R \& D$ policies and their effects on the incentives that drive private $R \& D$ investment. While much work remains to be done, recent progress has been rapid and very productive. The improved insights look certain to improve further in future work, and the subject is set to remain prominent in the academic and policy debate for some time to come. 


\section{BIBLIOGRAPHY}

Abramovsky, L. and Simpson, H. (2011) Geographic proximity and firm-university innovation linkages: Evidence from Great Britain. Journal of Economic Geography 11: 949-977.

Abramovsky, L., Harrison, R. and Simpson, H. (2007) University research and the location of business R\&D. Economic Journal 117: C114-C141.

Abramovsky, L., Kremp, E., Lopez, A., Schmidt, T. and Simpson, H. (2009) Understanding co-operative innovative activity: evidence from four European countries. Economics of Innovation and New Technology 18: 243-265.

Acs, Z.J. and Audretsch, D.B. (1988) Innovation in large and small firms. An empirical analysis. American Economic Review 78: 678-690

Adams, J.D. (2002) Comparative localization of academic and industrial spillovers. Journal of Economic Geography 2: 253-278.

Adams, J.D., Chiang, E.P. and Jensen, J.L. (2003) The influence of federal laboratory R\&D on industrial research. Review of Economics and Statistics 85: 1003-1020.

Adams, J.D., Chiang, E.P. and Starkey, K. (2001) Industry-university cooperative research centers. Journal of Technology Transfer 26: 73-86.

Aerts, K. and Schmidt, T. (2008) Two for the price of one? Additionality effects of R\&D subsidies: A comparison between Flanders and Germany. Research Policy 37: 806-822.

Almus, M. and Czarnitzki, D. (2003) The effects of public R\&D subsidies on firms innovation activities. The case of Eastern Germany. Journal of Business and Economic Statistics 21: 226-236.

Anderson, T. and Hsiao, C. (1982) Formulation and estimation of dynamic models using panel data. Journal of Econometrics 18: 869-881.

Arellano, M. and Bond, S.R. (1991) Some tests of specification for panel data: Monte Carlo evidence and an application to employment equations. Review of Economic Studies 58: 277-297.

Arrow, K.J. (1962a) The economic implications of learning by doing. Review of Economic Studies 29: 155-173.

Arrow, K.J. (1962b) Economic welfare and the allocation of resources to invention. In Nelson, R.R. (Ed.) The Rate and Direction of Inventive Activity. Princeton University Press: 609-625.

Autant-Bernard, C. (2001) Science and knowledge flows: Evidence from the French case. Research Policy 30: 1069-1078.

Baghana, R. and Mohnen, P. (2009) Effectiveness of R\&D tax incentives in small and large enterprises in Québec. Small Business Economics 33: 91-107. 
Becker, B. and Hall, S.G. (2013) Do R\&D strategies in high-tech sectors differ from those in low-tech sectors? - An alternative approach to testing the pooling assumption. Economic Change and Restructuring 46: 138-202.

Becker, B. and Pain, N. (2008) What determines industrial R\&D expenditure in the UK? Manchester School 76: 66-87.

Belderbos, R., Carree, M., Diederen, B., Lokshin, B. and Veugelers, R. (2004) Heterogeneity in R\&D cooperation strategies. International Journal of Industrial Organization 22: $1237-$ 1263.

Bernstein, J.I. and Mamuneas, T.P. (2005) Depreciation estimation, R\&D capital stock, and North American manufacturing productivity growth. Annales d'Économie et de Statistique 79/80: 383-404.

Bloch, C. and Graversen, E.K. (2012) Additionality of public R\&D funding for business R\&D - A dynamic panel data analysis. World Review of Science, Technology and Sustainable Development 9: 204-220.

Bloom, N. and Griffith, R. (2001) The internationalisation of UK R\&D. Fiscal Studies 22: 337-355.

Bloom, N., Griffith, R. and Van Reenen, J. (2002) Do R\&D tax credits work? Evidence from an international panel of countries 1979-97. Journal of Public Economics 85: 1-31.

Blundell, R.W. and Bond, S.R. (1998) Initial conditions and moment restrictions in dynamic panel data models. Journal of Econometrics 87: 115-143.

Blundell, R.W., Bond, S.R. and Windmeijer, F. (2000) Estimation in dynamic panel data models: Improving on the performance of the standard GMM estimator. In B. Baltagi (Ed) Advances in Econometrics, Vol. 15: Nonstationary Panels, Panel Cointegration, and Dynamic Panels. JAI Elsevier Science.

Bond, S., Harhoff, D. and Van Reenen, J. (2005) Investment, R\&D and financial constraints in Britain and Germany. Annales d'Économie et de Statistique 79/80: 435-463.

Bound, J., Cummins, C., Griliches, Z., Hall, B.H. and Jaffe, A. (1984) Who does R\&D and who patents? In Griliches, Z. (Ed.) $R \& D$, Patents, and Productivity. Chicago: University of Chicago Press.

Bound, J., Jaeger, D.A. and Baker, R.M. (1995) Problems with instrumental variables estimation when the correlation between the instruments and the endogenous explanatory variable is weak. Journal of the American Statistical Association 90: 443-450.

Bravo-Ortega, C. and Marin, A.G. (2011): R\&D and productivity: A two-way avenue? World Development 39: 1090-1107.

Caloghirou, Y., Ioannides, S. and Vonortas, N. (2003) Research joint ventures. Journal of Economic Surveys 17: 541-570.

Cameron, G., Proudman, J. and Redding, S. (2005) Technological convergence, R\&D, trade and productivity growth. European Economic Review 49: 775-807. 
Carboni, O.A. (2011) R\&D subsidies and private R\&D expenditures: Evidence from Italian manufacturing data. International Review of Applied Economics 25: 419-439.

Cassiman, B. and Veugelers, R. (2002) R\&D cooperation and spillovers: Some empirical evidence from Belgium. American Economic Review 92: 1169-1184.

Cerulli, G. and Potì, B. (2012) Evaluating the robustness of the effect of public subsidies on firms' R\&D: An application to Italy. Journal of Applied Economics 15: 287-320.

Cincera, M., Czarnitzki, D. and Thorwarth, S. (2011) Efficiency of public spending in support of R\&D activities. Reflets et Perspectives de la Vie Economique 1-2: 131-139.

Coe, D.T., Helpman, E. and Hoffmaister, A.W. (2009) International R\&D spillovers and institutions. European Economic Review 53: 723-741.

Cohen, W.M. and Mowery, D.C. (1984) The internal characteristics of the firm and the level and composition of research \& development spending. Interim report, National Science Foundation, Carnegie-Mellon University, as mentioned in Cohen, W.M. and Levin, R.C. (1989) Empirical studies of innovation and market structure. In Schmalensee, R. and Willig, R.D. (Eds.) Handbook of Industrial Organisation II. Amsterdam: North-Holland: 1065 .

Czarnitzki, D. (2006) Research and development in small and medium-sized enterprises: The role of financial constraints and public funding. Scottish Journal of Political Economy 53: 335-357.

Czarnitzki, D.and Hottenrott, H. (2012) Collaborative R\&D as a strategy to attenuate financing constraints. ZEW Discussion Paper 12-049.

Czarnitzki, D. and Hussinger, K. (2004) The link between R\&D subsidies, R\&D spending and technological performance. ZEW Discussion Paper 04-56.

Czarnitzki, D. and Licht, G. (2006) Additionality of public R\&D grants in a transition economy. Economics of Transition 14: 101-131.

Czarnitzki, D. and Lopes Bento, C. (2011) Innovation subsidies: Does the funding source matter for innovation intensity and performance? Empirical evidence from Germany. CEPS/INSTEAD Working Paper 2011-42.

Czarnitzki, D. and Lopes Bento, C. (2012) Evaluation of public R\&D policies: A crosscountry comparison. World Review of Science, Technology and Sustainable Development 9: $254-282$.

Czarnitzki, D. and Lopes Bento, C. (2013) Value for money? New microeconometric evidence on public R\&D grants in Flanders. Research Policy 42: 76-89.

Czarnitzki, D., Ebersberger, B. and Fier, A. (2007) The relationship between R\&D collaboration, subsidies and R\&D performance: Empirical evidence from Finland and Germany. Journal of Applied Econometrics 22: 1347-1366.

Czarnitzki, D., Hanel, P. and Rosa, J.M. (2011) Evaluating the impact of R\&D tax credits on innovation: A microeconometric study on Canadian firms. Research Policy 40: 217-229. 
D'Aspremont, C. and Jacquemin, A. (1988) Cooperative and noncooperative R\&D in duopoly with spillovers. American Economic Review 78: 1133-1137.

David, P.A., Hall, B.H. and Toole, A.A. (2000) Is public R\&D a complement or substitute for private R\&D? A review of the econometric evidence. Research Policy 29: 497-529.

Dixit, A.K. (1988) International R\&D competition and policy. In: Hazard, H.A. and Spence, A.M. (Eds) International Competitiveness. Cambridge, MA: Ballinger.

Dorfman, N.S. (1983) The development of a regional high technology economy. Research Policy 12: 299-316.

Duguet, E. (2004) Are R\&D subsidies a substitute or a complement to privately funded R\&D? Evidence from France using propensity score methods for non-experimental data. Revue D'Economie Politique 114: 263-292.

Eisner, R. and Strotz, R.H. (1993) Determinants of business investment. In: Commission on Money and Credit, Impacts of Monetary Policy. New Jersey: Prentice Hall, Englewood Cliffs: 59-233.

Falk, M. (2006) What drives business Research and Development (R\&D) intensity across Organisation for Economic Co-operation and Development (OECD) countries? Applied Economics 38: 533-547.

Feldman, M.P. and Kelley, M.R. (2006) The ex ante assessment of knowledge spillovers: Government R\&D policy, economic incentives and private firm behavior. Research Policy 35: $1509-1521$.

Furman, J.L., Kyle, M.K., Cockburn, I. and Henderson, R. (2006) Public \& private spillovers, location and the productivity of pharmaceutical research. Annales d'Économie et de Statistique 79-80.

García, A. and Mohnen, P. (2010) Impact of government support on R\&D and innovation. United Nations University MERIT Working Paper 2010-034.

García-Quevedo, J. (2004) Do public subsidies complement business R\&D? A meta-analysis of the econometric evidence. Kyklos 57: 87-102.

González, X. and Pazó, C. (2008) Do public subsidies stimulate private R\&D spending? Research Policy 37: 371-389.

González, X., Jaumandreu, J. and Pazó, C. (2005) Barriers to innovation and subsidy effectiveness. RAND Journal of Economics 36: 930-950.

Görg, H. and Strobl, E. (2007) The effect of R\&D subsidies on private R\&D. Economica 74: 215-234.

Griliches, Z. (1979) Issues in assessing the contribution of research and development to productivity growth. Bell Journal of Economics 10: 92-116.

Griliches, Z. (1998) $R \& D$ and Productivity: The Econometric Evidence. Chicago: University of Chicago Press. 
Grossman, G.M. and Helpman, D. (1991) Innovation and Growth in the Global Economy. Cambridge, MA: MIT Press.

Guellec, D. and Van Pottelsberghe de la Potterie, B. (2001) R\&D and productivity growth: Panel data analysis of 16 OECD countries. OECD Economic Studies 33: 103-127.

Guellec, D. and Van Pottelsberghe de la Potterie, B. (2003) The impact of public R\&D expenditure on business R\&D. Economics of Innovation and New Technology 12: 225243.

Hagedoorn, J. (2002) Inter-firm R\&D partnerships: An overview of major trends and patterns since 1960. Research Policy 31: 477-492.

Hagedoorn, J. and Narula, R. (1996) Choosing organizational modes of strategic technology partnering: International and sectoral differences. Journal of International Business Studies 27: 265-284.

Hagedoorn, J., Link, A. and Vonortas, N. (2000) Research partnerships. Research Policy 29: 567-586.

Hall, B.H. (1991) Firm level investment with liquidity constraints. What can the Euler equations tell us? University of California at Berkeley and National Bureau of Economic Research, http://emlab.berkeley.edu/users/bhhall/bhpapers.html\#rnd.

Hall, B.H. (1993) R\&D tax policy during the eighties: Success or failure? Tax Policy and the Economy 7: 1-36.

Hall, B.H. (2002) The financing of research and development. Oxford Review of Economic Policy 18: 35-51.

Hall, B.H. (2006) Research and Development. In Darity, W.A. (Ed) International Encyclopedia of the Social Sciences, 2nd edition (http://emlab.berkeley.edu/users/bhhall/ bhpapers.html\#rnd).

Hall, B.H. and Lerner, J. (2010) The financing of R\&D and innovation. In: Hall, B.H. and Rosenberg, N. (Eds.) Handbook of the Economics of Innovation. Elsevier/North Holland.

Hall, B.H. and Van Reenen, J. (2000) How effective are fiscal incentives for R\&D? A review of the evidence. Research Policy 29: 449-469.

Hall, B.H., Griliches, Z. and Hausman, J.A. (1986) Patents and R\&D: Is there a lag? International Economic Review 7: 265-283.

Hall, B.H., Link, A.N. and Scott, J.T. (2001) Barriers inhibiting industry from partnering with universities: Evidence from the Advanced Technology Program. Journal of Technology Transfer 26: 87-98.

Hall, B.H., Link, A.N. and Scott, J.T. (2003) Universities as research partners. Review of Economics and Statistics 85: 485-491.

Hall, B.H., Lotti, F. and Mairesse, J. (2009) Innovation and productivity in SMEs: Empirical evidence for Italy. Small Business Economics 33: 13-33. 
Harris, R., Li, Q.C. and Trainor, M. (2009) Is a higher rate of R\&D tax credit a panacea for low levels of R\&D in disadvantaged regions? Research Policy 38: 192-205.

Henningsen, M., Haegeland, T. and Møen, J. (2012) Estimating the additionality of R\&D subsidies using proposal evaluation data to control for firms' R\&D intentions. Statistics Norway Discussion Paper 729.

Hussinger, K. (2008) R\&D and subsidies at the firm level: An application of parametric and semiparametric two-step selection models. Journal of Applied Econometrics 23: 729-747.

Hyytinen, A. and Toivanen, O. (2005) Do financial constraints hold back innovation and growth? Evidence on the role of public policy. Research Policy 34: 1385-1403.

Irwin, D.A. and Klenow, P.J. (1996) High-tech R\&D subsidies: Estimating the effects of Sematech. Journal of International Economics 40: 323-344.

Jaffe, A.B. (1989) Real effects of academic research. American Economic Review 79: 957970.

Jaffe, A.B. (2002) Building programme evaluation into the design of public research-support programmes. Oxford Review of Economic Policy 18: 22-34.

Kafouros, M.I. (2005) R\&D and productivity growth: Evidence from the UK. Economics of Innovation and New Technology 14: 479-497.

Kamien, M.I., Mueller, E. and Zang, I. (1992) Research joint ventures and R\&D cartels. American Economic Review 82: 1293-1306.

Kanwar, S. and Evenson, R. (2003) Does intellectual property protection spur technological change? Oxford Economic Papers 55: 235-264.

Karlsson, C. and Andersson, M. (2009) The location of industry R\&D and the location of university R\&D - How are they related? In: Karlsson, C., Andersson, A.E., Cheshire, P.C. and Stough, R.R. (Eds.) New Directions in Regional Economic Development. Advances in Spatial Science. Dordrecht and New York: Springer: 267-290.

Kesteloot, K. and Veugelers, R. (1995) Stable R\&D cooperation with spillovers. Journal of Economics and Management Strategy 4: 651-672

Klette, T.J. and Møen, J. (2012) R\&D investment responses to R\&D subsidies: A theoretical analysis and a microeconometric study. World Review of Science, Technology and Sustainable Development 9: 169-203.

Klette, T.J., Møen, J. and Griliches, Z. (2000) Do subsidies to commercial R\&D reduce market failures? Microeconomic evaluation studies. Research Policy 29: 471-495.

Koga, T. (2003) Firm size and R\&D tax incentives. Technovation 23: 643-648.

Krugman, P. (1991a) Increasing returns and economic geography. Journal of Political Economy 99: 483-499.

Krugman, P. (1991b) Geography and Trade. Cambridge, MA: MIT Press. 
Lach, S. (2002) Do R\&D subsidies stimulate or displace private R\&D? Evidence from Israel. Journal of Industrial Economics 50: 369-390.

Lach, S. and Schankerman, M. (1989) Dynamics of R\&D investment in the scientific sector. Journal of Political Economy 97: 880-904.

Lokshin, B. and Mohnen, P. (2012) How effective are level-based R\&D tax credits? Evidence from the Netherlands. Applied Economics 44: 1527-1538.

López-García, P.L., Montero, J.M. and Moral-Benito, E. (2012) Business cycles and investment in intangibles: Evidence from Spanish firms. Banco De España Working Paper 1219.

Lucas, R.E. (1967) Adjustment costs and the theory of supply. Journal of Political Economy 75: $321-334$

Mairesse, J., Hall, B.H. and Mulkay, B. (1999) Firm-level investment in France and the United States: An exploration of what we have learned in twenty years. Annales d'Économie et de Statistique 55-6: 27-69.

Marshall, A. (1920) Principles of Economics. 8th edition. London: Macmillan.

Meuleman, M. and De Maeseneire, W. (2012) Do R\&D subsidies affect SMEs' access to external financing? Research Policy 41: 580-591.

Mulkay, B. and Mairesse, J. (2013) The R\&D tax credit in France: Assessment and ex-ante evaluation of the 2008 reform. NBER Working Paper 19073.

Nelson R.R. (1959) The simple economics of basic scientific research. Journal of Political Economy 67: 297-306.

Nelson, R.R. (1986) Institutions supporting technical advance in industry. American Economic Review 76, Papers and Proceedings: 186-189.

Nickell, S.J. (1981) Biases in dynamic models with fixed effects. Econometrica 49: 13991416.

OECD (2002) The Measurement of Scientific and Technological Activities: Proposed Standard Practice for Surveys on Research and Experimental Development. 'Frascati Manual'. Paris: OECD.

O'Mahony, M. and Vecchi, M. (2009) R\&D, knowledge spillovers and company productivity performance. Research Policy 38: 35-44.

Özçelik, E. and Taymaz, E. (2008) R\&D support programs in developing countries: The Turkish experience. Research Policy 37: 258-275.

Parisi, M.L. and Sembenelli, A. (2003) Is private R\&D spending sensitive to its price? Empirical evidence on panel data for Italy. Empirica 30: 357-377.

Ponds, R., Van Oort, F. and Frenken, K. (2007) The geographical and institutional proximity of research collaboration. Papers in Regional Science 86: 423-444. 
Proudman, J. and Redding, S.J. (1998, Eds.) Openness and Growth. London: Bank of England.

Romer, P.M. (1986) Increasing returns and long-run growth. Journal of Political Economy 94: 1002-1037.

Romer, P.M. (1990) Endogenous technological change. Journal of Political Economy 98: S71-S102.

Rosa, J.M. and Mohnen, P. (2008) Knowledge transfers between Canadian business enterprises and universities: Does distance matter? Annales d'Économie et de Statistique 87/88: 303-323.

Schmidt, T. (2005) Knowledge flows and R\&D co-operation: Firm-level evidence from Germany. ZEW Discussion Paper 05-22.

Schumpeter, J.A. (1939) Business Cycles. London: Allen and Unwin.

Schumpeter, J.A. (1942) Capitalism, Socialism, and Democracy. New York: Harper.

Sena, V. (2004) The return of the Prince of Denmark: A survey on recent developments in the economics of innovation. Economic Journal 114: F312-332.

Shapiro, C. and Willig, R.D. (1990) On the antitrust treatment of production joint ventures. Journal of Economic Perspectives 43: 113-30.

Tobin, J. (1969) A general equilibrium approach to monetary policy. Journal of Money, Credit and Banking 1: 15-29.

Veugelers, R. and Cassiman, B. (2005) R\&D cooperation between firms and universities. Some empirical evidence from Belgian manufacturing. International Journal of Industrial Organization 23: 355-379.

Wang, E.C. (2010) Determinants of R\&D investment: The extreme-bounds-analysis approach applied to 26 OECD countries. Research Policy 39: 103-116.

Woodward, D., Figueiredo, O. and Guimaraes, P. (2006) Beyond the Silicon Valley: University R\&D and high-technology location. Journal of Regional Science 60: 15-32.

Yang, C.-H., Huang, C.-H. and Hou, T. C.-T. (2012) Tax incentives and R\&D activity: Firmlevel evidence from Taiwan. Research Policy 41: 1578-1588. 
Table 1. Studies on R\&D tax credits and direct subsidies

\begin{tabular}{|c|c|c|c|c|c|c|c|c|}
\hline $\begin{array}{c}\text { Study / } \\
\text { Estimation Methodology }\end{array}$ & \begin{tabular}{|c|}
$\begin{array}{c}\text { Tax Credit or } \\
\text { Subsidy }\end{array}$ \\
\end{tabular} & \begin{tabular}{|l|} 
Country/ies \\
\end{tabular} & $\begin{array}{c}\text { Level of } \\
\text { Aggregation }\end{array}$ & R\&D Policy Variables & Effect & Control Variables & Effect & Period \\
\hline $\begin{array}{l}\text { BLOOM, GRIFFITH, VAN REENEN } \\
(2002) \\
I V(\log \text {-log) } \\
\text { - Dv: (industry-funded) R\&D } \\
\text { expenditure / output } \\
\text { - The results are reported from } \\
\text { the authors' preferred dynamic } \\
\text { specification which imposes } \\
\text { constant returns. }\end{array}$ & tax credit & $\begin{array}{l}\text { Australia, } \\
\text { G7, Spain }\end{array}$ & $\begin{array}{l}\text { countries } \\
\text { (panel data) }\end{array}$ & user cost of $R \& D$ & $\mathrm{~s}(-)(\mathrm{s} / \mathrm{r}$ and $\mathrm{l} / \mathrm{r})$ & $\begin{array}{l}\text { ldv } \\
\text { country dummies } \\
\text { time dummies }\end{array}$ & $\mathrm{s}$ & $\begin{array}{l}1979- \\
97\end{array}$ \\
\hline $\begin{array}{l}\text { LACH (2002) } \\
\text { Pooled difference-in-difference } \\
\text { estimator } \\
\text { - The results are reported from } \\
\text { the final specification. }\end{array}$ & subsidy & Israel & $\begin{array}{l}\text { firms } \\
\text { (panel data) }\end{array}$ & $\begin{array}{l}\text { subsidy } \\
\text { subsidyt-1 }\end{array}$ & 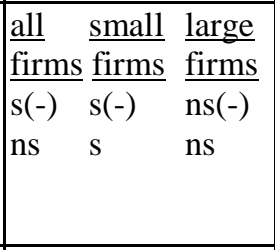 & $\begin{array}{l}\text { employment } \\
\text { industry dummies } \\
\text { time dummies }\end{array}$ & $\begin{array}{|lll|}\underline{\text { all }} & \underline{\mathrm{s}} & \underline{1} \\
\mathrm{~s} & \mathrm{~ns} & \mathrm{~ns}\end{array}$ & $\begin{array}{l}1991- \\
95\end{array}$ \\
\hline $\begin{array}{l}\text { GUELLEC, VAN POTTESLBERGHE } \\
\text { DE LA POTTERIE (2003) } \\
\text { IV (3SLS, log-log, first- } \\
\text { differences) } \\
\text { - The results are reported from } \\
\text { the regression that tests directly } \\
\text { for (and finds) a non-linear } \\
\text { inverted U-curve subsidy effect. }\end{array}$ & $\begin{array}{l}\text { tax credit } \\
\text { and subsidy }\end{array}$ & \begin{tabular}{|l|} 
Australia, \\
Belgium, \\
Denmark, \\
Finland, G7, \\
Ireland, \\
Netherlands, \\
Norway, \\
Spain, \\
Sweden, \\
Switzerland \\
\end{tabular} & \begin{tabular}{|l} 
countries \\
(business \\
sector \\
aggregates; \\
panel data)
\end{tabular} & $\begin{array}{l}\text { B-index of fiscal generosity to- } \\
\text { wards } R \& D_{t-1}=(\text { after-tax cost } \\
\text { of a } 1 \$ R \& D \text { investment }) /(1- \\
\text { corporate income tax rate }) \\
\text { interaction term of subsidy } y_{t-1} \\
\text { and share of subsidy in total } \\
\text { business-performed } R \& D_{t-1} \\
\text { interaction term of subsidy } y_{t-1} \\
\text { and squared share of subsidy } \\
\text { in total business-performed } \\
\text { R\&D } D_{t-1}\end{array}$ & $\begin{array}{l}\mathrm{s}(-) \\
\mathrm{s} \\
\mathrm{s}(-)\end{array}$ & 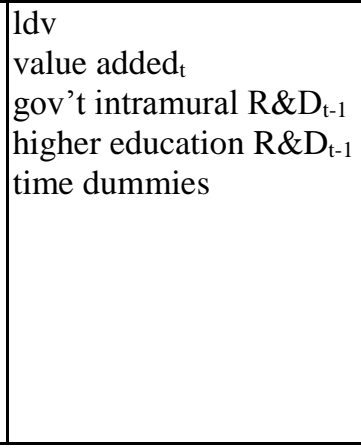 & $\begin{array}{l}\mathrm{ns}(10 \% \mathrm{~s}) \\
\mathrm{s} \\
\mathrm{s}(-) \\
\mathrm{ns}(-)\end{array}$ & $\begin{array}{l}1981- \\
1996\end{array}$ \\
\hline
\end{tabular}

Note: The dependent variable is R\&D expenditure unless mentioned otherwise. $D v$ and $l d v$ denote dependent variable and lagged dependent variable, respectively. $S$ ( $n s$ ) denotes significance (insignificance) of the coefficient at the $5 \%$ or higher level. $S / r(l / r)$ denote short-run (long-run) coefficient. (-) denotes negative coefficient. $\Delta_{t}$ is first difference. The abbreviations GLS, GMM, IV, OLS, and $3 S L S$ follow the conventional ways to denote generalised least squares, generalised method of moments, instrumental variables, ordinary least squares, and three stage least squares. Gov't denotes government, log denotes logarithm or natural logarithm. Dummy variables distinguishing between a 'yes' or 'no' answer to a question were set equal to $1(0)$ when the answer was 'yes' ('no'), unless mentioned otherwise. 
Table 2. Studies on spillovers from university research and high-skilled human capital

\begin{tabular}{|c|c|c|c|c|c|c|c|}
\hline $\begin{array}{c}\text { Study / } \\
\text { Estimation Methodology }\end{array}$ & $\begin{array}{c}\text { Country/ } \\
\text { ies }\end{array}$ & \begin{tabular}{|c|} 
Level of \\
Aggregation
\end{tabular} & $\begin{array}{c}\text { University Research and Human Capital } \\
\text { Variables }\end{array}$ & Effect & Control Variables & Effect & Period \\
\hline $\begin{array}{l}\text { JAFFE (1989) } \\
I V(3 \text { SLS, log-log) } \\
\text { - The results are reported } \\
\text { from the all-areas industry } \\
\text { R\&D equation. }\end{array}$ & US & \begin{tabular}{|l|}
28 states \\
(pooled \\
cross-section \\
data)
\end{tabular} & $\begin{array}{l}\text { university research: spending by } \\
\text { departments (technical areas: drugs, } \\
\text { chemicals, electronics, mechanical arts, } \\
\text { all other) }\end{array}$ & $\mathrm{s}$ & $\begin{array}{l}\text { population } \\
\text { value added }\end{array}$ & $\begin{array}{l}\text { ns } \\
\text { s }\end{array}$ & $\begin{array}{l}1972-77 \\
1979 \\
1981\end{array}$ \\
\hline \begin{tabular}{|l|} 
ABRAMOVSKY, HARRISON, \\
SIMPSON (2007) \\
Negative binomial regression \\
- Dv: average number of \\
firms carrying out intramural \\
R\&D \\
- The results are reported \\
from the all-firms regression \\
for the pharmaceuticals \\
product group.
\end{tabular} & UK & \begin{tabular}{|l|} 
postcode \\
areas \\
(cross- \\
section data)
\end{tabular} & $\begin{array}{l}\text { presence of university, dummy: yes or no } \\
\text { number of universities } \\
\text { average university quality } \\
\text { number of univ. departments rated 1-4 } \\
\left.\text { [maximum quality: } 5^{*}\right] \text { : } \\
\text { biology } \\
\text { chemistry } \\
\text { medical } \\
\text { number of univ. dept's rated } 5 \text { and } 5^{*} \text { : } \\
\text { biology } \\
\text { chemistry } \\
\text { medical } \\
\text { no. of research students in } 1-4 \text { dept's } \\
\text { no. of research students in } 5,5^{*} \text { dept's }\end{array}$ & $\begin{array}{l}\text { ns(-) } \\
\text { ns (-) } \\
\text { ns } \\
\text { ns } \\
\text { s } \\
\text { ns } \\
\text { s(-) } \\
\text { s } \\
\text { ns } \\
\text { ns } \\
\text { ns }\end{array}$ & $\begin{array}{l}\text { total manufacturing employment }(\log ) \\
\text { diversification index }(=(1-\mathrm{H}) \times 100, \\
\text { where } \mathrm{H}=\text { sum of squared share of } \\
\text { employment in 4-digit industry i in } \\
\text { total manufacturing employment in } \\
\text { the postcode area) [index increasing } \\
\text { in extent of diversification] } \\
\% \text { of total manufacturing employment } \\
\text { that is in pharmaceuticals industry } \\
\% \text { of economically active population } \\
\text { that is qualified to degree equivalent } \\
\text { or above }\end{array}$ & $\begin{array}{l}\mathrm{s} \\
\mathrm{ns}\end{array}$ & 2000 \\
\hline $\begin{array}{l}\text { KANWAR, EVENSON (2003) } \\
\text { Random effects GLS (log- } \\
\text { log) } \\
\text { - Dv: R\&D / gross national } \\
\text { product } \\
\text { - The results are reported } \\
\text { from the preferred model of } \\
\text { the paper's exercise } 1 \text { that } \\
\text { includes the countries with } \\
\text { available data for all } \\
\text { variables considered in the } \\
\text { general-to-specific modelling } \\
\text { methodology. }\end{array}$ & & $\begin{array}{l}29 \text { countries } \\
(\text { panel data) }\end{array}$ & $\begin{array}{l}\text { average number of years of formal } \\
\text { schooling of the population aged } 15 \\
\text { years or above } e_{t}\end{array}$ & $\mathrm{~s}$ & $\begin{array}{l}\text { gross domestic savings / GDP (as a } \\
\text { proxy for internal funds available for } \\
\text { R\&D) } t-1 \\
\text { index of intellectual property (patent) } \\
\text { protection } \text { (values from } 0-5 \text { from } \\
\text { lowest to highest protection; index } \\
\text { incorporates five aspects of patent } \\
\text { laws: extent of coverage, } \\
\text { membership of international patent } \\
\text { agreements, duration of protection, } \\
\text { provisions for loss of protection, } \\
\text { enforcement mechanisms) }\end{array}$ & $\mathrm{s}$ & $\begin{array}{l}1985 \\
1990 \\
(5-\text { year } \\
\text { averages })\end{array}$ \\
\hline
\end{tabular}

Note: See Table 1 for the abbreviations and further notes. 
Table 3. Studies on formal R\&D cooperation

\begin{tabular}{|c|c|c|c|c|c|c|c|}
\hline $\begin{array}{c}\text { Study / } \\
\text { Estimation Methodology }\end{array}$ & $\begin{array}{c}\text { Country/ } \\
\text { ies }\end{array}$ & $\begin{array}{c}\text { Level of } \\
\text { Aggregation }\end{array}$ & $\begin{array}{c}\text { Cooperation, Spillovers and Human } \\
\text { Capital Variables }\end{array}$ & Effect & Control Variables & Effect & Period \\
\hline $\begin{array}{l}\text { ADAMS, CHIANG, STARKEY } \\
(2001) \\
\text { OLS } \\
\text { - Dv: laboratory R\&D }\end{array}$ & US & $\begin{array}{l}\text { R\&D } \\
\text { laboratories, } \\
\text { owned by } \\
\text { firms } \\
\text { (cross- } \\
\text { section data) }\end{array}$ & $\begin{array}{l}\text { member of Industry-University } \\
\text { Cooperative Research Center, dummy: } \\
\text { yes or no } \\
\text { number of PhD or MD scientists in the } \\
\text { laboratory (log) }\end{array}$ & $\mathrm{s}$ & $\begin{array}{l}\text { recent firm sales (log) } \\
\text { stock of firm's patents near the } \\
\text { laboratory over the past } 20 \text { years } t-1 \\
\text { share of lab science and engineering } \\
\text { fields in science rather than } \\
\text { engineering } \\
\text { R\&D in rest of firm }(\log )\end{array}$ & $\begin{array}{l}\mathrm{s} \\
\mathrm{s} \\
\mathrm{s} \\
\mathrm{s}(-)\end{array}$ & $\begin{array}{l}1991, \\
1996 \\
\text { (pooled) }\end{array}$ \\
\hline $\begin{array}{l}\text { ADAMS, CHIANG, JENSEN } \\
(2003) \\
O L S \\
\text { - Dv: company-financed } \\
\text { laboratory R\&D net of } \\
\text { expenditures on federal } \\
\text { laboratories (log) }\end{array}$ & US & $\begin{array}{l}\text { firms } \\
\text { (cross- } \\
\text { section data) }\end{array}$ & $\begin{array}{l}\text { member of Cooperative R\&D } \\
\text { Agreement between firms and } \\
\text { federal labs, dummy: yes or no } \\
\text { number of PhD scientists in the } \\
\text { laboratory (log) }\end{array}$ & $\mathrm{s}$ & $\begin{array}{l}\text { stock of sales over the last } 12 \text { years } \\
(\log ) \\
\text { R\&D in rest of firm (log) } \\
\text { dummies for lab characteristics } \\
\text { gov't contractor dummy: yes or no } \\
\text { value of procurement near the lab (log) } \\
\text { value of procurement in rest of firm } \\
\text { (log) } \\
\text { industry dummies } \\
\text { year dummies }\end{array}$ & $\begin{array}{l}\text { s } \\
\text { s(-) } \\
\text { vary } \\
\text { ns(-) } \\
\text { ns } \\
\text { ns }\end{array}$ & $\begin{array}{l}1991 \text { and } \\
1996 \\
\text { (average) }\end{array}$ \\
\hline $\begin{array}{l}\text { CASSIMAN, VEUGELERS } \\
\text { (2002) } \\
\text { Probit 2-step } \\
\text { - Dv: cooperation dummy: } \\
\text { yes or no (cooperation with } \\
\text { suppliers or customers or } \\
\text { competitors or public } \\
\text { research institutes or private } \\
\text { research institutes or } \\
\text { universities) } \\
\text { - The results are reported } \\
\text { from the specification that } \\
\text { controls for endogeneity and } \\
\text { excludes the insignificant } \\
\text { permanent R\&D variable. }\end{array}$ & Belgium & $\begin{array}{l}\text { firms } \\
\text { (cross- } \\
\text { section data) }\end{array}$ & $\begin{array}{l}\text { incoming spillovers (= sum of scores of } \\
\text { importance of following information } \\
\text { sources for innovation process, from } 1 \\
\text { (unimportant) to } 5 \text { (crucial): patent } \\
\text { information; specialised conferences, } \\
\text { meetings, publications; trade shows and } \\
\text { seminars (rescaled between } 0 \text { and } 1 \text { )) } \\
\text { appropriability (= sum of scores of } \\
\text { effectiveness of following methods for } \\
\text { protecting new products / processes, } \\
\text { from } 1 \text { (unimportant) to } 5 \text { (crucial): } \\
\text { secrecy; complexity of product or } \\
\text { process design; lead time on competitors; } \\
\text { (rescaled between } 0 \text { and } 1 \text { )) }\end{array}$ & $\begin{array}{c}\mathrm{ns}(10 \% \\
\mathrm{s})\end{array}$ & $\begin{array}{l}\text { industry level (mean) of legal } \\
\text { protection, where industry level is } \\
\text { defined at 2-digit NACE (= sum of } \\
\text { scores of effectiveness of following } \\
\text { methods or protecting new products / } \\
\text { processes, from } 1 \text { (unimportant) to } 5 \\
\text { (crucial): patents; registration of } \\
\text { brands, copyright (rescaled between } \\
0 \text { and 5)) } \\
\text { size (= firm sales in } 1992 \text { in } 10^{10} \\
\text { Belgian francs) } \\
\text { size squared } \\
\text { cost (= sum of scores of importance of } \\
\text { following obstacles to innovation } \\
\text { process, from } 1 \text { (unimportant) to } 5 \\
\text { (crucial): no suitable financing }\end{array}$ & \begin{tabular}{|l}
$\mathrm{ns}$ \\
\\
$\mathrm{ns}(10 \%$ \\
$\mathrm{s})$ \\
$\mathrm{ns}(-, 10$ \\
$\% \mathrm{~s})$ \\
$\mathrm{s}$
\end{tabular} & 1993 \\
\hline
\end{tabular}




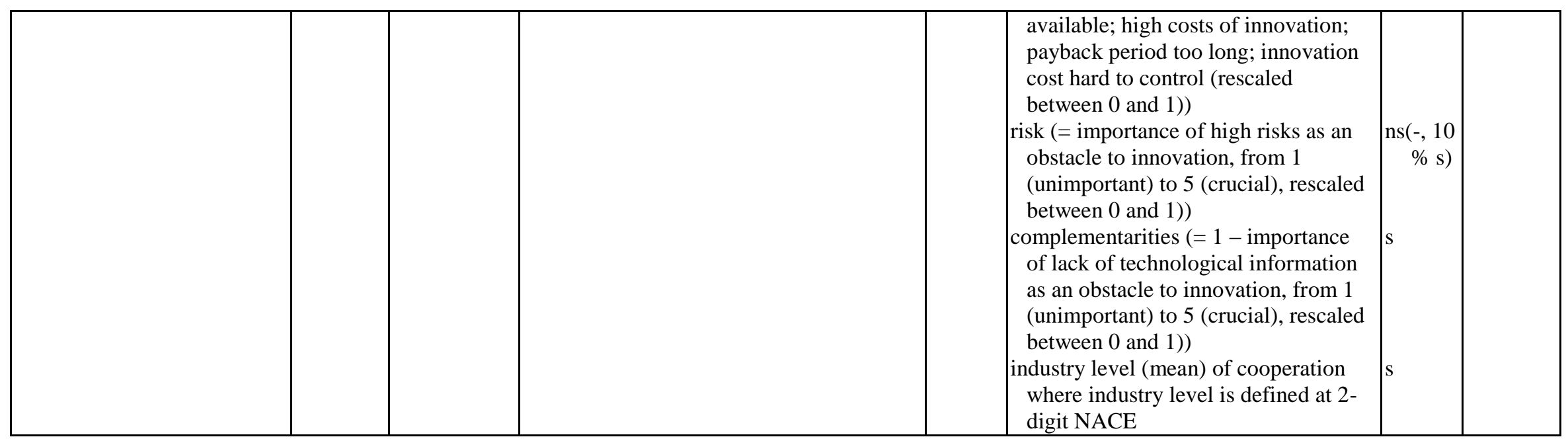

Note: See Table 1 for the abbreviations and further notes. 
Table 1. Studies on R\&D tax credits and direct subsidies

\begin{tabular}{|c|c|c|c|c|c|c|c|c|}
\hline $\begin{array}{c}\text { Study / } \\
\text { Estimation Methodology }\end{array}$ & \begin{tabular}{|c|}
$\begin{array}{c}\text { Tax Credit or } \\
\text { Subsidy }\end{array}$ \\
\end{tabular} & \begin{tabular}{|l|} 
Country/ies \\
\end{tabular} & $\begin{array}{c}\text { Level of } \\
\text { Aggregation }\end{array}$ & R\&D Policy Variables & Effect & Control Variables & Effect & Period \\
\hline $\begin{array}{l}\text { BLOOM, GRIFFITH, VAN REENEN } \\
(2002) \\
I V(\log \text {-log) } \\
\text { - Dv: (industry-funded) R\&D } \\
\text { expenditure / output } \\
\text { - The results are reported from } \\
\text { the authors' preferred dynamic } \\
\text { specification which imposes } \\
\text { constant returns. }\end{array}$ & tax credit & $\begin{array}{l}\text { Australia, } \\
\text { G7, Spain }\end{array}$ & $\begin{array}{l}\text { countries } \\
\text { (panel data) }\end{array}$ & user cost of $R \& D$ & $\mathrm{~s}(-)(\mathrm{s} / \mathrm{r}$ and $\mathrm{l} / \mathrm{r})$ & $\begin{array}{l}\text { ldv } \\
\text { country dummies } \\
\text { time dummies }\end{array}$ & $\mathrm{s}$ & $\begin{array}{l}1979- \\
97\end{array}$ \\
\hline $\begin{array}{l}\text { LACH (2002) } \\
\text { Pooled difference-in-difference } \\
\text { estimator } \\
\text { - The results are reported from } \\
\text { the final specification. }\end{array}$ & subsidy & Israel & $\begin{array}{l}\text { firms } \\
\text { (panel data) }\end{array}$ & $\begin{array}{l}\text { subsidy } \\
\text { subsidyt-1 }\end{array}$ & 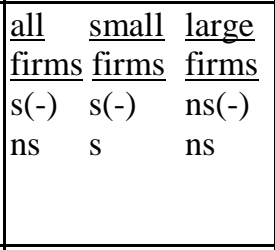 & $\begin{array}{l}\text { employment } \\
\text { industry dummies } \\
\text { time dummies }\end{array}$ & $\begin{array}{|lll|}\underline{\text { all }} & \underline{\mathrm{s}} & \underline{1} \\
\mathrm{~s} & \mathrm{~ns} & \mathrm{~ns}\end{array}$ & $\begin{array}{l}1991- \\
95\end{array}$ \\
\hline $\begin{array}{l}\text { GUELLEC, VAN POTTESLBERGHE } \\
\text { DE LA POTTERIE (2003) } \\
\text { IV (3SLS, log-log, first- } \\
\text { differences) } \\
\text { - The results are reported from } \\
\text { the regression that tests directly } \\
\text { for (and finds) a non-linear } \\
\text { inverted U-curve subsidy effect. }\end{array}$ & $\begin{array}{l}\text { tax credit } \\
\text { and subsidy }\end{array}$ & \begin{tabular}{|l|} 
Australia, \\
Belgium, \\
Denmark, \\
Finland, G7, \\
Ireland, \\
Netherlands, \\
Norway, \\
Spain, \\
Sweden, \\
Switzerland \\
\end{tabular} & \begin{tabular}{|l} 
countries \\
(business \\
sector \\
aggregates; \\
panel data)
\end{tabular} & $\begin{array}{l}\text { B-index of fiscal generosity to- } \\
\text { wards } R \& D_{t-1}=(\text { after-tax cost } \\
\text { of a } 1 \$ R \& D \text { investment }) /(1- \\
\text { corporate income tax rate }) \\
\text { interaction term of subsidy } y_{t-1} \\
\text { and share of subsidy in total } \\
\text { business-performed } R \& D_{t-1} \\
\text { interaction term of subsidy } y_{t-1} \\
\text { and squared share of subsidy } \\
\text { in total business-performed } \\
\text { R\&D } D_{t-1}\end{array}$ & $\begin{array}{l}\mathrm{s}(-) \\
\mathrm{s} \\
\mathrm{s}(-)\end{array}$ & 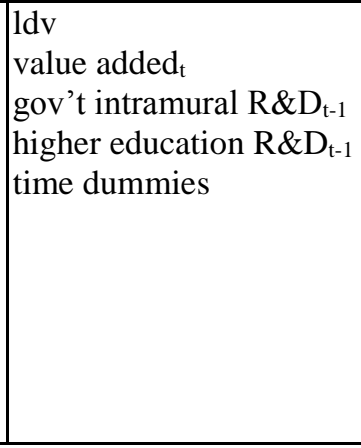 & $\begin{array}{l}\mathrm{ns}(10 \% \mathrm{~s}) \\
\mathrm{s} \\
\mathrm{s}(-) \\
\mathrm{ns}(-)\end{array}$ & $\begin{array}{l}1981- \\
1996\end{array}$ \\
\hline
\end{tabular}

Note: The dependent variable is R\&D expenditure unless mentioned otherwise. $D v$ and $l d v$ denote dependent variable and lagged dependent variable, respectively. $S$ ( $n s$ ) denotes significance (insignificance) of the coefficient at the $5 \%$ or higher level. $S / r(l / r)$ denote short-run (long-run) coefficient. (-) denotes negative coefficient. $\Delta_{t}$ is first difference. The abbreviations GLS, GMM, IV, OLS, and $3 S L S$ follow the conventional ways to denote generalised least squares, generalised method of moments, instrumental variables, ordinary least squares, and three stage least squares. Gov't denotes government, log denotes logarithm or natural logarithm. Dummy variables distinguishing between a 'yes' or 'no' answer to a question were set equal to 1 (0) when the answer was 'yes' ('no'), unless mentioned otherwise. 
Table 2. Studies on spillovers from university research and high-skilled human capital

\begin{tabular}{|c|c|c|c|c|c|c|c|}
\hline $\begin{array}{c}\text { Study / } \\
\text { Estimation Methodology }\end{array}$ & $\begin{array}{c}\text { Country/ } \\
\text { ies }\end{array}$ & $\begin{array}{c}\text { Level of } \\
\text { Aggregation }\end{array}$ & $\begin{array}{c}\text { University Research and Human Capital } \\
\text { Variables }\end{array}$ & Effect & Control Variables & Effect & Period \\
\hline $\begin{array}{l}\text { JAFFE (1989) } \\
I V(3 \text { SLS, log-log) } \\
\text { - The results are reported } \\
\text { from the all-areas industry } \\
\text { R\&D equation. }\end{array}$ & US & $\begin{array}{l}28 \text { states } \\
\text { (pooled } \\
\text { cross-section } \\
\text { data) }\end{array}$ & $\begin{array}{l}\text { university research: spending by } \\
\text { departments (technical areas: drugs, } \\
\text { chemicals, electronics, mechanical arts, } \\
\text { all other) }\end{array}$ & $\mathrm{s}$ & $\begin{array}{l}\text { population } \\
\text { value added }\end{array}$ & $\begin{array}{l}\text { ns } \\
\mathrm{s}\end{array}$ & $\begin{array}{l}1972-77 \\
1979 \\
1981\end{array}$ \\
\hline $\begin{array}{l}\text { ABRAMOVSKY, HARRISON, } \\
\text { SIMPSON (2007) } \\
\text { Negative binomial regression } \\
\text { - Dv: average number of } \\
\text { firms carrying out intramural } \\
\text { R\&D } \\
\text { - The results are reported } \\
\text { from the all-firms regression } \\
\text { for the pharmaceuticals } \\
\text { product group. }\end{array}$ & UK & $\begin{array}{l}\text { postcode } \\
\text { areas } \\
\text { (cross- } \\
\text { section data) }\end{array}$ & $\begin{array}{l}\text { presence of university, dummy: yes or no } \\
\text { number of universities } \\
\text { average university quality } \\
\text { number of univ. departments rated 1-4 } \\
\left.\text { [maximum quality: } 5^{*}\right] \text { : } \\
\text { biology } \\
\text { chemistry } \\
\text { medical } \\
\text { number of univ. dept's rated } 5 \text { and } 5^{*} \text { : } \\
\text { biology } \\
\text { chemistry } \\
\text { medical } \\
\text { no. of research students in } 1-4 \text { dept's } \\
\text { no. of research students in } 5,5^{*} \text { dept's }\end{array}$ & $\begin{array}{l}\text { ns(-) } \\
\text { ns (-) } \\
\text { ns } \\
\text { ns } \\
\text { s } \\
\text { ns } \\
\text { s(-) } \\
\text { s } \\
\text { ns } \\
\text { ns } \\
\text { ns }\end{array}$ & $\begin{array}{l}\text { total manufacturing employment }(\mathrm{log}) \\
\text { diversification index }(=(1-\mathrm{H}) \times 100, \\
\text { where } \mathrm{H}=\text { sum of squared share of } \\
\text { employment in 4-digit industry i in } \\
\text { total manufacturing employment in } \\
\text { the postcode area) [index increasing } \\
\text { in extent of diversification] } \\
\% \text { of total manufacturing employment } \\
\text { that is in pharmaceuticals industry } \\
\% \text { of economically active population } \\
\text { that is qualified to degree equivalent } \\
\text { or above }\end{array}$ & $\begin{array}{l}\mathrm{s} \\
\mathrm{ns}\end{array}$ & 2000 \\
\hline $\begin{array}{l}\text { KANWAR, EVENSON (2003) } \\
\text { Random effects GLS (log- } \\
\text { log) } \\
\text { - Dv: R\&D / gross national } \\
\text { product } \\
\text { - The results are reported } \\
\text { from the preferred model of } \\
\text { the paper's exercise } 1 \text { that } \\
\text { includes the countries with } \\
\text { available data for all } \\
\text { variables considered in the } \\
\text { general-to-specific modelling } \\
\text { methodology. }\end{array}$ & & $\begin{array}{l}29 \text { countries } \\
\text { (panel data) }\end{array}$ & $\begin{array}{l}\text { average number of years of formal } \\
\text { schooling of the population aged } 15 \\
\text { years or above } \mathrm{t}_{\mathrm{t}}\end{array}$ & $\mathrm{s}$ & $\begin{array}{l}\text { gross domestic savings / GDP (as a } \\
\text { proxy for internal funds available for } \\
\text { R\&D) } \mathrm{t}-1 \\
\text { index of intellectual property (patent) } \\
\text { protection } \mathrm{t} \text { (values from 0-5 from } \\
\text { lowest to highest protection; index } \\
\text { incorporates five aspects of patent } \\
\text { laws: extent of coverage, } \\
\text { membership of international patent } \\
\text { agreements, duration of protection, } \\
\text { provisions for loss of protection, } \\
\text { enforcement mechanisms) }\end{array}$ & $\mathrm{s}$ & $\begin{array}{l}1985, \\
1990 \\
(5-\text { year } \\
\text { averages })\end{array}$ \\
\hline
\end{tabular}

Note: See Table 1 for the abbreviations and further notes. 
Table 3. Studies on formal R\&D cooperation

\begin{tabular}{|c|c|c|c|c|c|c|c|}
\hline $\begin{array}{c}\text { Study / } \\
\text { Estimation Methodology } \\
\end{array}$ & $\begin{array}{c}\text { Country/ } \\
\text { ies }\end{array}$ & \begin{tabular}{|c|} 
Level of \\
Aggregation \\
\end{tabular} & $\begin{array}{c}\text { Cooperation, Spillovers and Human } \\
\text { Capital Variables }\end{array}$ & Effect & Control Variables & Effect & Period \\
\hline $\begin{array}{l}\text { ADAMS, CHIANG, STARKEY } \\
(2001) \\
O L S \\
\text { - Dv: laboratory R\&D }\end{array}$ & US & $\begin{array}{l}\text { R\&D } \\
\text { laboratories, } \\
\text { owned by } \\
\text { firms } \\
\text { (cross- } \\
\text { section data) }\end{array}$ & $\begin{array}{l}\text { member of Industry-University } \\
\text { Cooperative Research Center, dummy: } \\
\text { yes or no } \\
\text { number of PhD or MD scientists in the } \\
\text { laboratory (log) }\end{array}$ & $\mathrm{s}$ & $\begin{array}{l}\text { recent firm sales }(\log ) \\
\text { stock of firm's patents near the } \\
\text { laboratory over the past } 20 \text { years } t-1 \\
\text { share of lab science and engineering } \\
\text { fields in science rather than } \\
\text { engineering } \\
\text { R\&D in rest of firm }(\log )\end{array}$ & $\begin{array}{l}\mathrm{s} \\
\mathrm{s} \\
\mathrm{s} \\
\mathrm{s}(-)\end{array}$ & $\begin{array}{l}1991, \\
1996 \\
\text { (pooled) }\end{array}$ \\
\hline $\begin{array}{l}\text { ADAMS, CHIANG, JENSEN } \\
(2003) \\
O L S \\
\text { - Dv: company-financed } \\
\text { laboratory R\&D net of } \\
\text { expenditures on federal } \\
\text { laboratories (log) }\end{array}$ & US & $\begin{array}{l}\text { firms } \\
\text { (cross- } \\
\text { section data) }\end{array}$ & $\begin{array}{l}\text { member of Cooperative R\&D } \\
\text { Agreement between firms and } \\
\text { federal labs, dummy: yes or no } \\
\text { number of PhD scientists in the } \\
\text { laboratory (log) }\end{array}$ & $\mathrm{s}$ & $\begin{array}{l}\text { stock of sales over the last } 12 \text { years } \\
\text { (log) } \\
\text { R\&D in rest of firm (log) } \\
\text { dummies for lab characteristics } \\
\text { gov't contractor dummy: yes or no } \\
\text { value of procurement near the lab (log) } \\
\text { value of procurement in rest of firm } \\
\text { (log) } \\
\text { industry dummies } \\
\text { year dummies }\end{array}$ & $\begin{array}{l}\text { s } \\
\text { s(-) } \\
\text { vary } \\
\text { ns(-) } \\
\text { ns } \\
\text { ns }\end{array}$ & $\begin{array}{l}1991 \text { and } \\
1996 \\
\text { (average) }\end{array}$ \\
\hline $\begin{array}{l}\text { CASSIMAN, VEUGELERS } \\
\text { (2002) } \\
\text { Probit 2-step } \\
\text { - Dv: cooperation dummy: } \\
\text { yes or no (cooperation with } \\
\text { suppliers or customers or } \\
\text { competitors or public } \\
\text { research institutes or private } \\
\text { research institutes or } \\
\text { universities) } \\
\text { - The results are reported } \\
\text { from the specification that } \\
\text { controls for endogeneity and } \\
\text { excludes the insignificant } \\
\text { permanent R\&D variable. }\end{array}$ & Belgium & $\begin{array}{l}\text { firms } \\
\text { (cross- } \\
\text { section data) }\end{array}$ & $\begin{array}{l}\text { incoming spillovers (= sum of scores of } \\
\text { importance of following information } \\
\text { sources for innovation process, from } 1 \\
\text { (unimportant) to } 5 \text { (crucial): patent } \\
\text { information; specialised conferences, } \\
\text { meetings, publications; trade shows and } \\
\text { seminars (rescaled between } 0 \text { and } 1 \text { )) } \\
\\
\text { appropriability (= sum of scores of } \\
\text { effectiveness of following methods for } \\
\text { protecting new products / processes, } \\
\text { from } 1 \text { (unimportant) to } 5 \text { (crucial): } \\
\text { secrecy; complexity of product or } \\
\text { process design; lead time on competitors; } \\
\text { (rescaled between } 0 \text { and } 1 \text { )) }\end{array}$ & $\begin{array}{c}\mathrm{ns}(10 \% \\
\mathrm{s})\end{array}$ & $\begin{array}{l}\text { industry level (mean) of legal } \\
\text { protection, where industry level is } \\
\text { defined at 2-digit NACE (= sum of } \\
\text { scores of effectiveness of following } \\
\text { methods or protecting new products / } \\
\text { processes, from } 1 \text { (unimportant) to } 5 \\
\text { (crucial): patents; registration of } \\
\text { brands, copyright (rescaled between } \\
0 \text { and 5)) } \\
\text { size (= firm sales in } 1992 \text { in } 10^{10} \\
\text { Belgian francs) } \\
\text { size squared } \\
\text { cost (= sum of scores of importance of } \\
\text { following obstacles to innovation } \\
\text { process, from } 1 \text { (unimportant) to } 5 \\
\text { (crucial): no suitable financing }\end{array}$ & $\begin{array}{c}\mathrm{ns}(10 \% \\
\mathrm{s}) \\
\mathrm{ns}(-, 10 \\
\% \mathrm{~s}) \\
\mathrm{s}\end{array}$ & 1993 \\
\hline
\end{tabular}




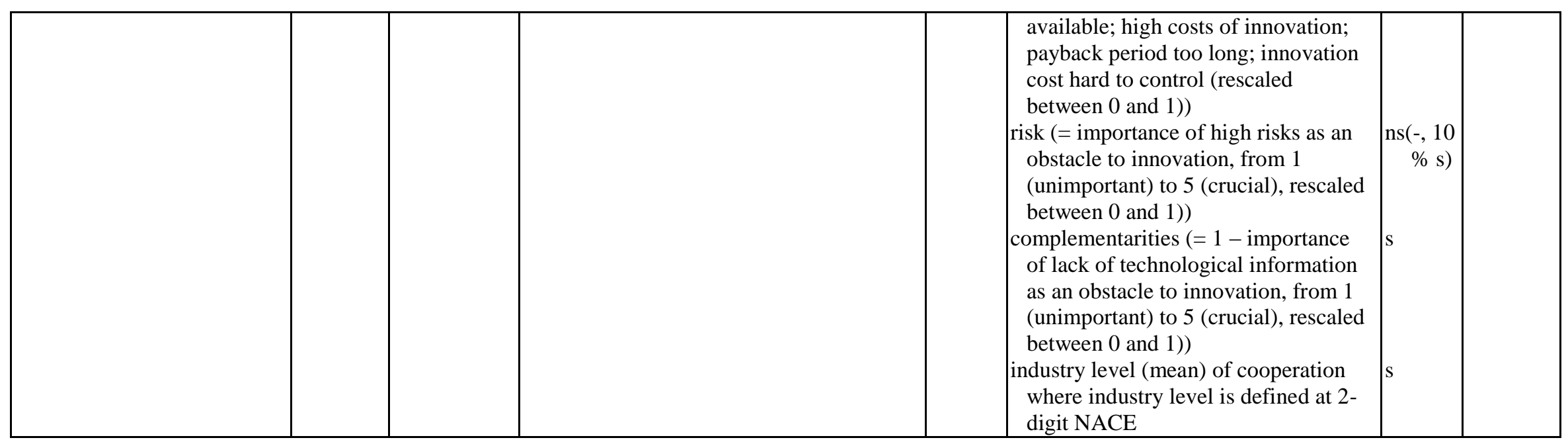

Note: See Table 1 for the abbreviations and further notes. 